
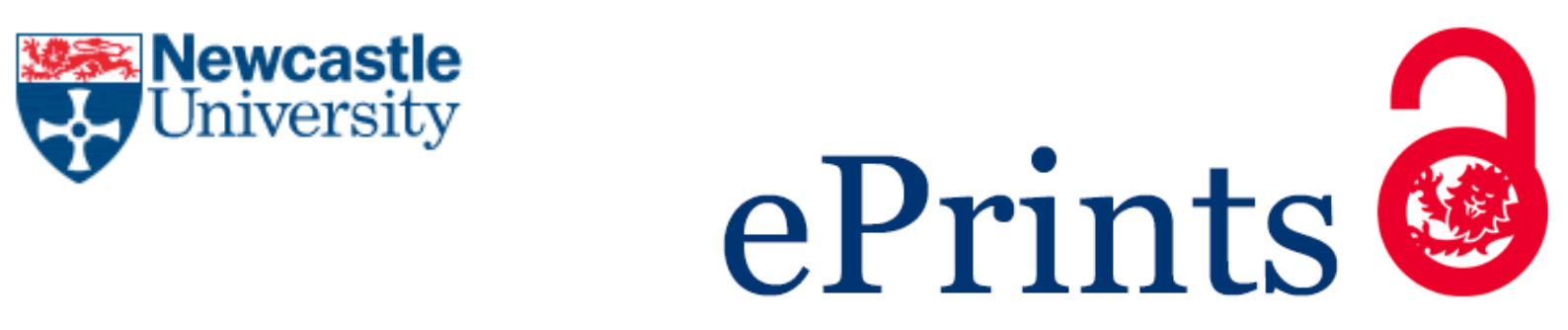

\title{
Brownlee IA.
}

The impact of dietary fibre intake on the physiology and health of the stomach and upper gastrointestinal tract. Bioactive Carbohydrates and Dietary Fibre 2014, 4(2), 155-169.

\section{Copyright:}

This is the author's version of a work accepted for publication. (C) 2014, Elsevier Ltd. Licensed under the Creative Commons Attribution-NonCommercial-NoDerivatives 4.0 International Licence.

DOI link to article:

http://dx.doi.org/10.1016/i.bcdf.2014.09.005

Date deposited:

$30 / 10 / 2014$

Embargo release date:

05 October 2015

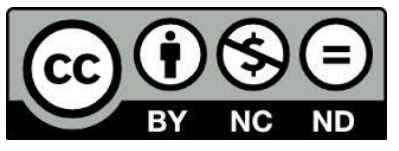

This work is licensed under a

Creative Commons Attribution-NonCommercial-NoDerivatives 4.0 International licence 


\section{elsevier_BCDF_68}

\section{The impact of dietary fibre intake on the physiology and health of the stomach and upper gastrointestinal tract}

\section{givennamelain Brownleesurname*}

iain.brownlee@ncl.ac.uk

Human Nutrition Research Centre, Newcastle University (Singapore Campus),University, Singapore Campus, Nanyang Polytechnic, Singapore, 569830Singapore 569830, Singapore

${ }^{*}$ Corresponding author. Tel.: +65 65500148.

\section{Abstract}

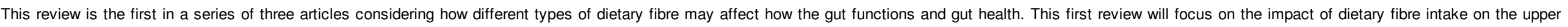

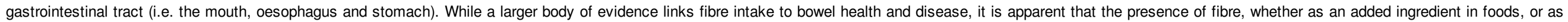

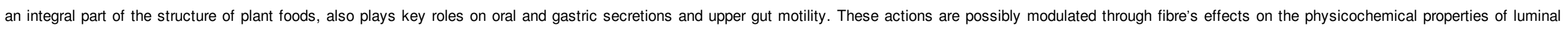
contents in the gut.

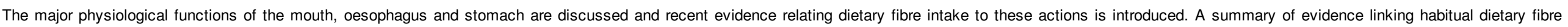
consumption to major mucosal diseases of the upper gastrointestinal tract is also provided.

Keywords: Dietary fibre; Mastication; Swallowing; Saliva; Gastric juice; Upper gastrointestinal eancer.cancer

\section{Introduction}

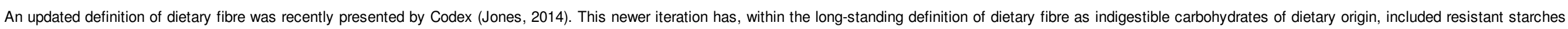

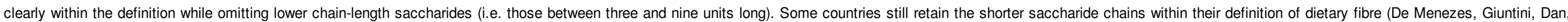

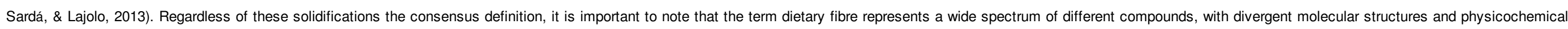

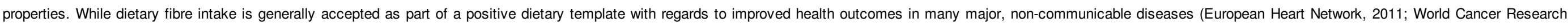

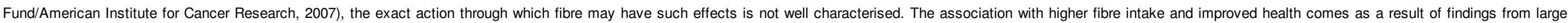

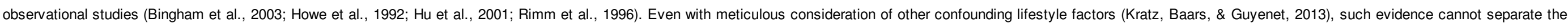

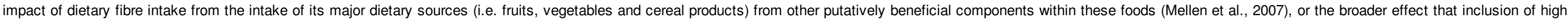
amounts of these foods within the diet may have to displace other less optimal food choices (Bogart et al., 2014; Lazzeri et al., 2013).

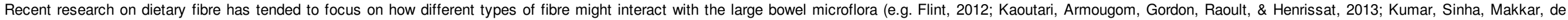

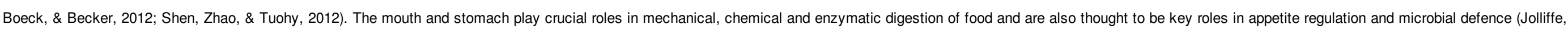

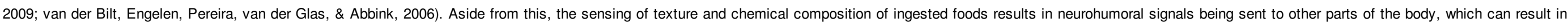
acute and long-term changes to whole body metabolism (Côté, Zadeh-Tahmasebi, Rasmussen, Duca, \& Lam, 2014; Depoortere, 2014; Chen, 2011):2011).

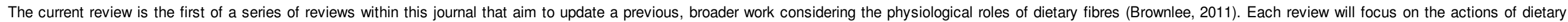

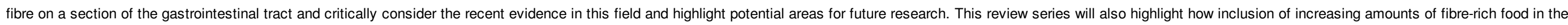

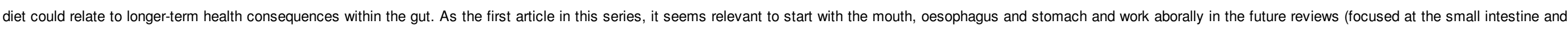
large intestine).

\section{Bolus production in the mouth}




\section{elsevier_BCDF_68}

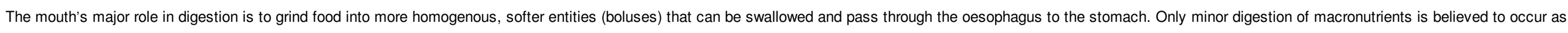

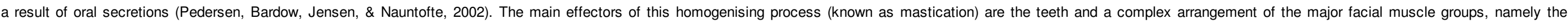

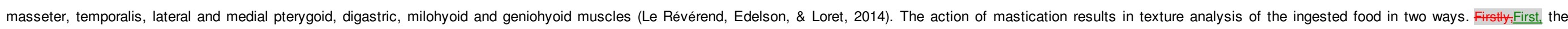

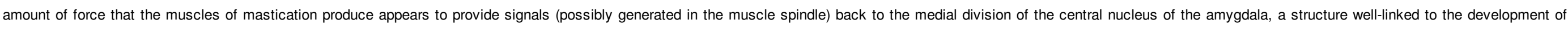

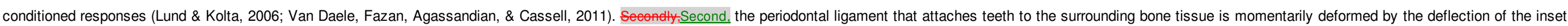

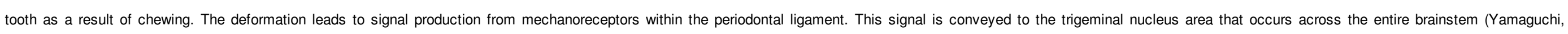

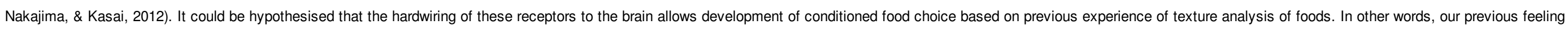

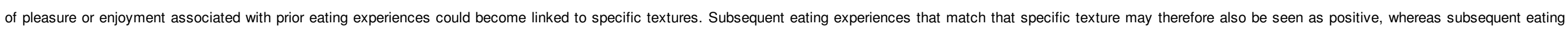
experiences that do not match previous texture expectations may be viewed negatively. It must be noted that this would be extremely difficult to evidence experimentally.

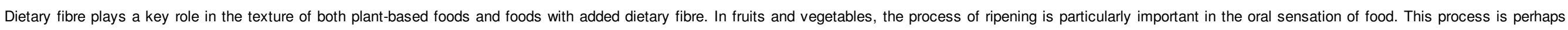

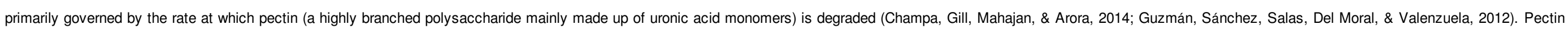

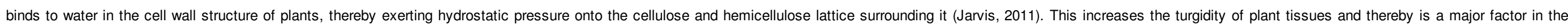

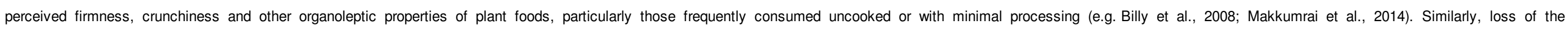

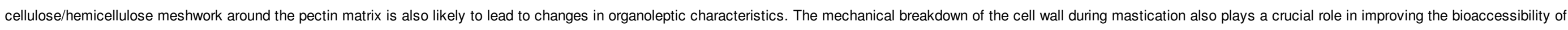
plant nutrients (e.g. Ellis et al., 2004) and is likely to affect the taste perception of these foods (Tarascou et al., 2010).

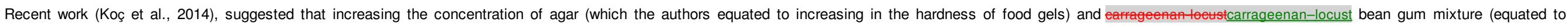

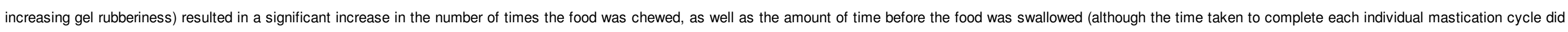

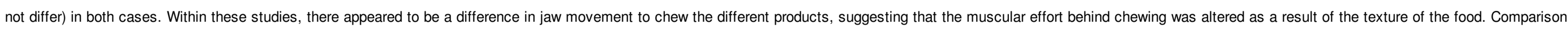

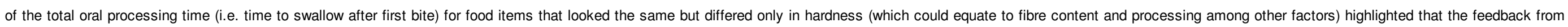
the oral sensory organ rapidly results reduced energy intake and increased oral processing time (Bolhuis et al., 2014).

\section{Swallowing and the oesophagus}

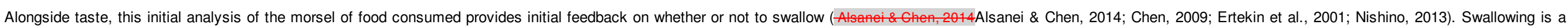

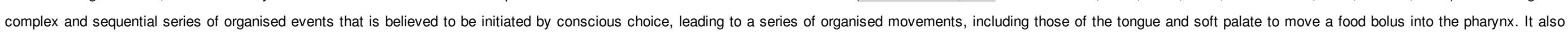

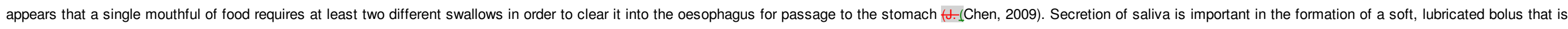

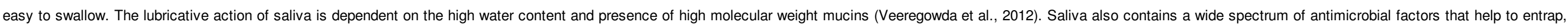

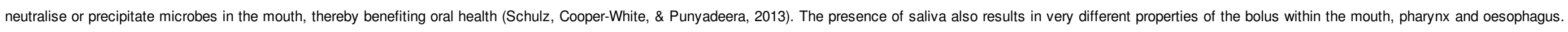

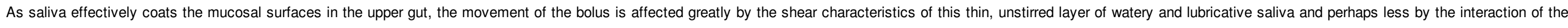
bolus and mucosal surface than had classically been considered (J._Chen, Liu, \& Prakash, 2014).

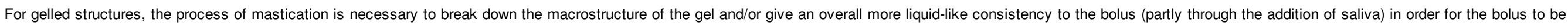

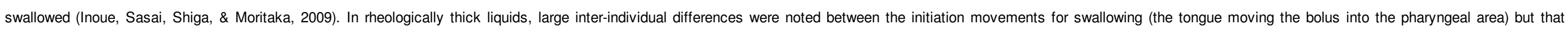
increasing bolus viscosity correlated with increasing time to complete each swallow, even though higher viscosity was also associated with lower fluid intake at each sip (Steele \& Van Lieshout, 2004).

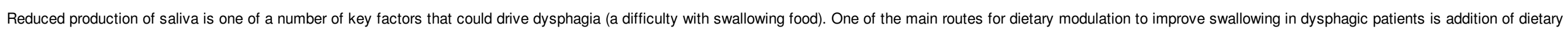

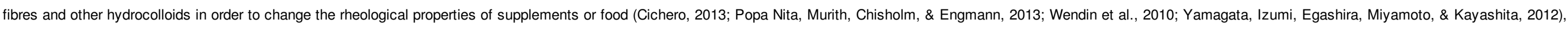

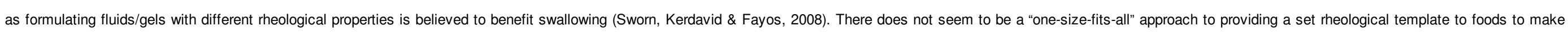
them easier to swallow but the broad spectrum of viscous and gel-forming polysaccharides available does allow design of products tailored to patient needs.

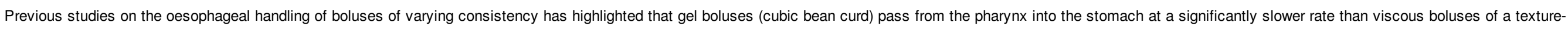




\section{elsevier_BCDF_68}

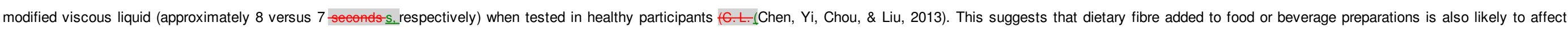

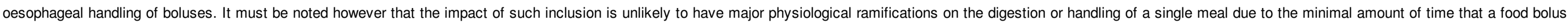

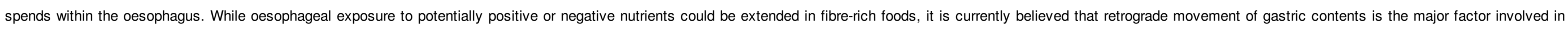
oesophageal disease and this will be discussed below.

\section{Gastric motility}

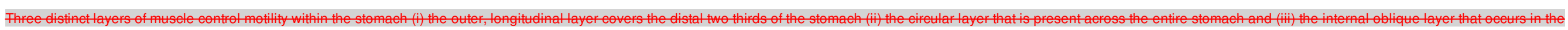

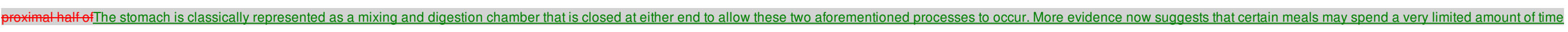
in the stomach prior to passage to the stomach (small intestine. Shafik, El Sibai, Shafik, \& Shafik, 2007). For example ...

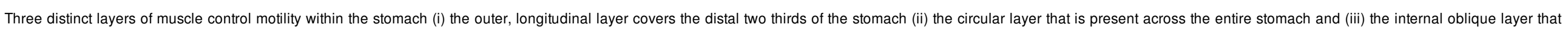
occurs in the proximal half of the stomach (Shafik, El Sibai, Shafik, \& Shafik, 2007).

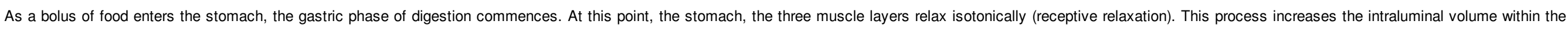

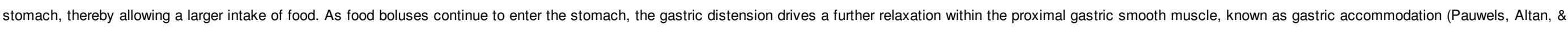

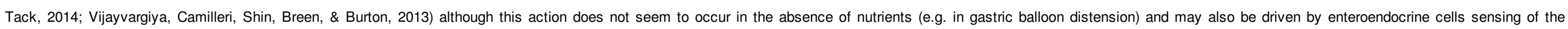

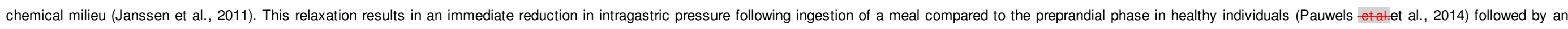
increase in pressure as the meal continues.

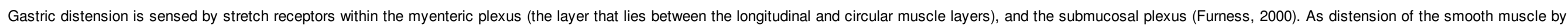

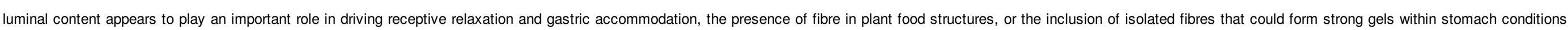

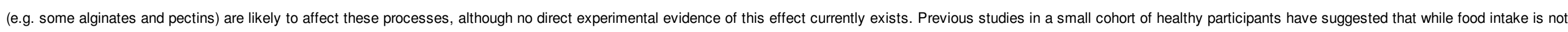

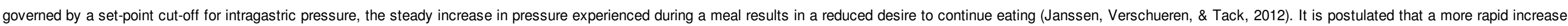
in pressure would result in stopping reaching a state of satiation more rapidly at a single meal compared to the same meal without the volume occupied by fibre wateffibre-water matrices.

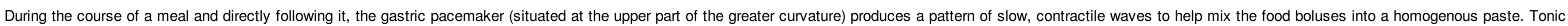

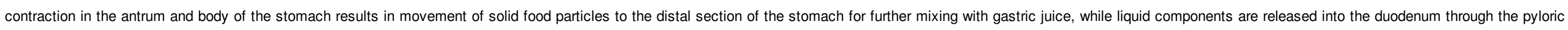

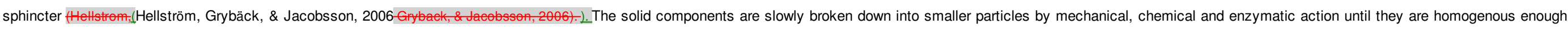
to pass through the pylorus and into the duodenum.

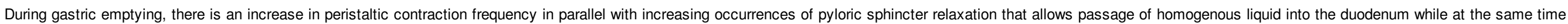

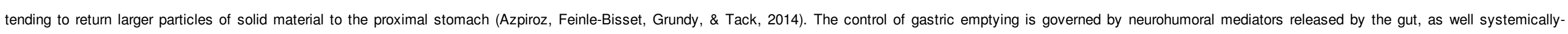

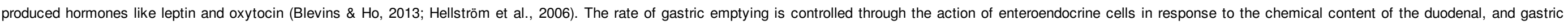

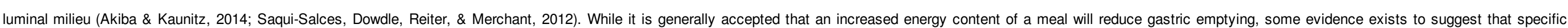

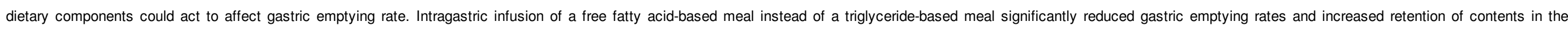

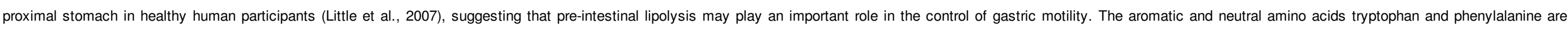
known to be strong stimulators of the release of a range of duodenally secreted hormones (secretin, motilin, gastric inhibitory peptide and cholecystokinin) which are believed to delay gastric emptying (Buchan, 1999).

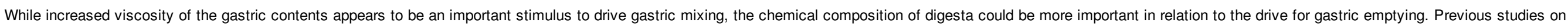

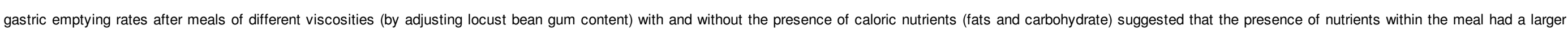

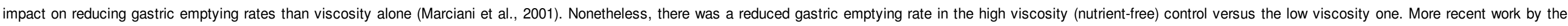

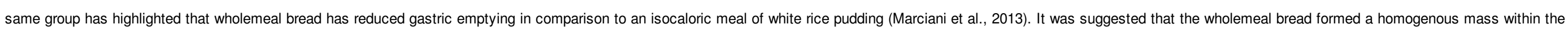




\section{elsevier_BCDF_68}

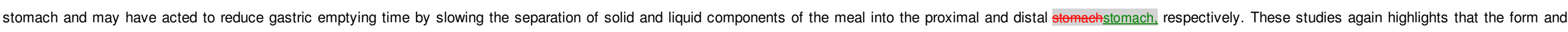

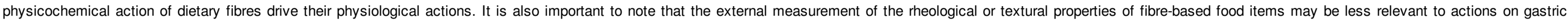

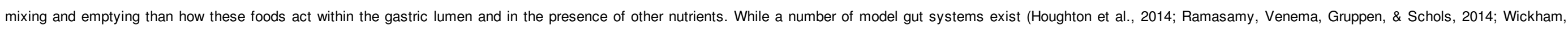

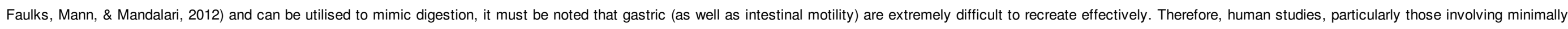
invasive methods like MRI, are invaluable in the design of fibre-based formulations with targeted physiological actions.

\section{Gastric involvement in satiation and satiety}

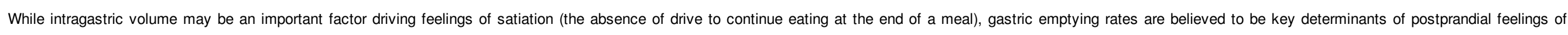

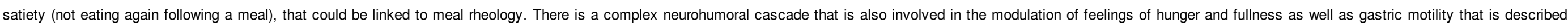

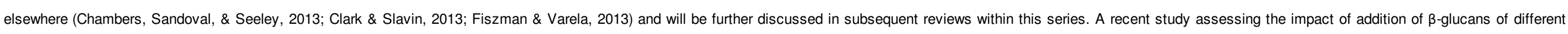

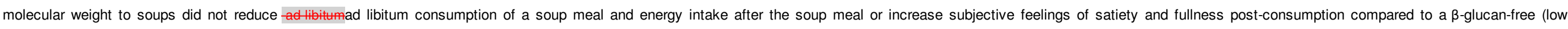

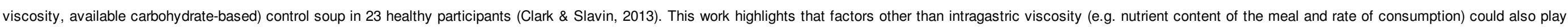
an important role in satiety.

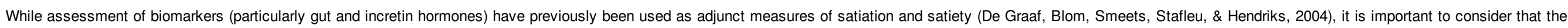

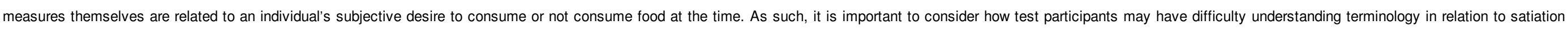

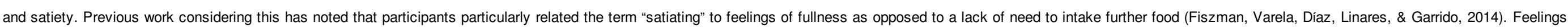

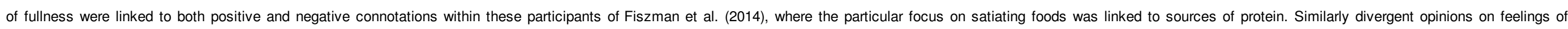

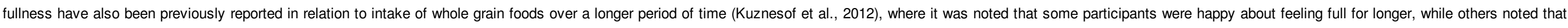

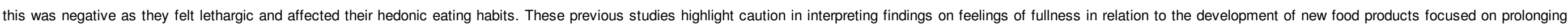
satiety or inducing satiation.

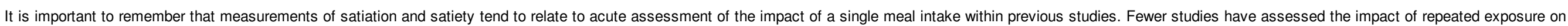

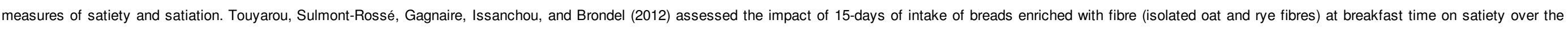

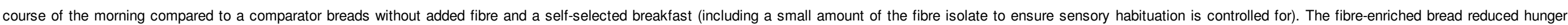

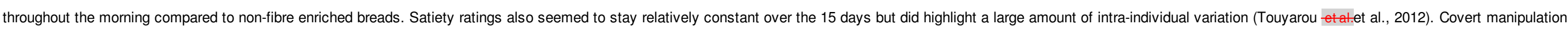

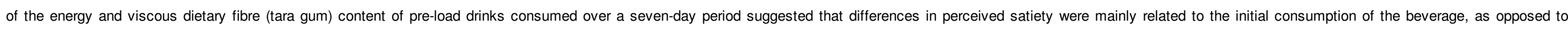

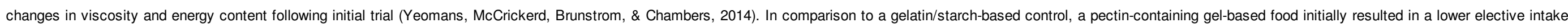

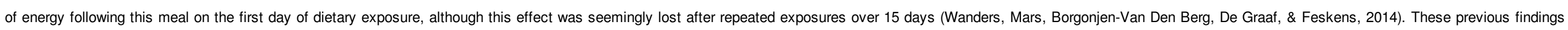

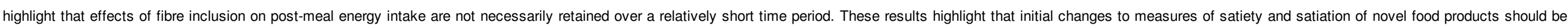
extrapolated to longer-term changes on eating habits and efficacy as weight management adjuncts with caution.

\section{Gastric exocrine and endocrine secretion}

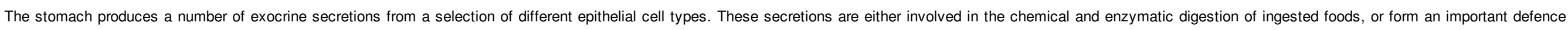

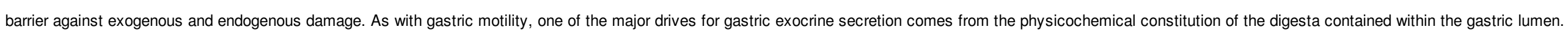

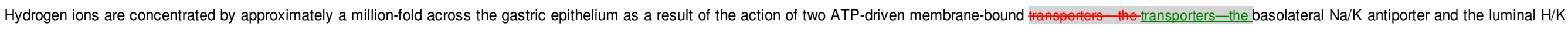

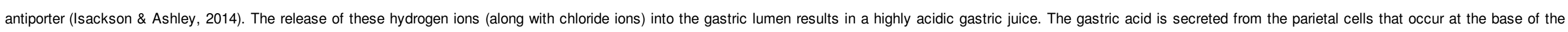

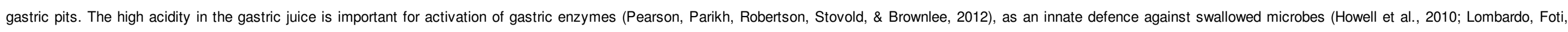
Ruggia, \& Chiecchio, 2010) and to denature dietary proteins to aid in both homogenisation of gastric contents and allow improved access of proteolytic enzymes sites of cleavage (Herman, Gao, \& Storer, 2006). 


\section{elsevier_BCDF_68}

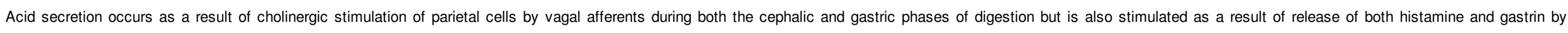

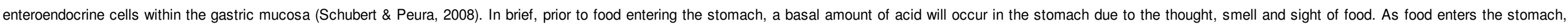

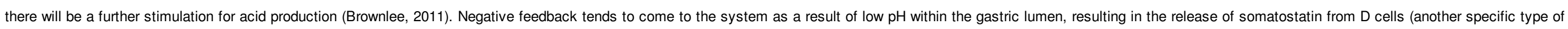
enteroendocrine cell) which inhibits further stimulation of parietal secretion (Isackson \& Ashley, 2014).

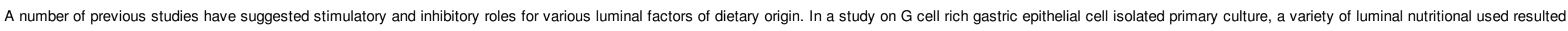

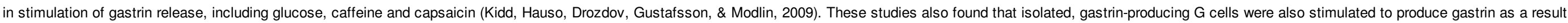

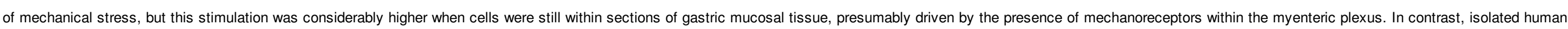

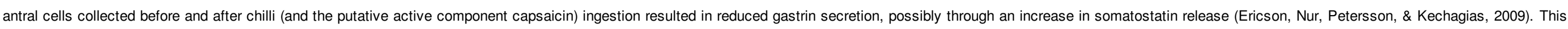

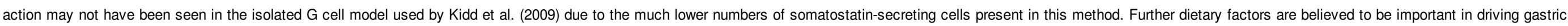

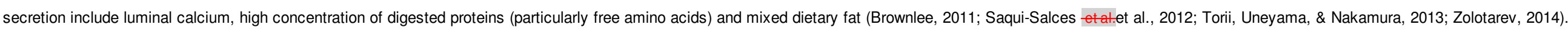

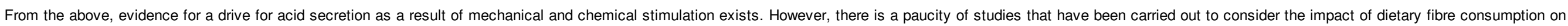

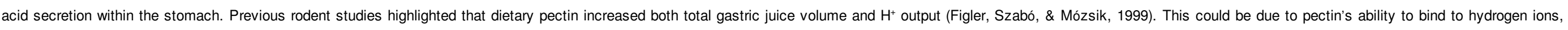

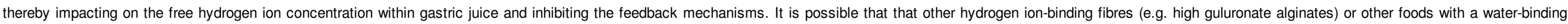

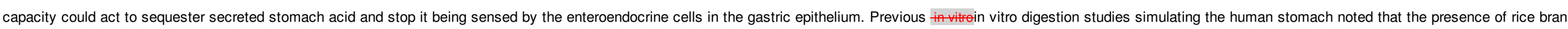

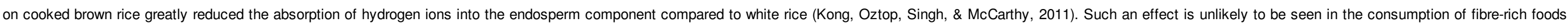
that have a high water content and relatively high acidity (e.g. many fruits and vegetables).

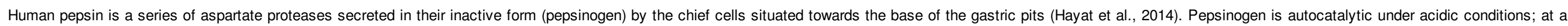

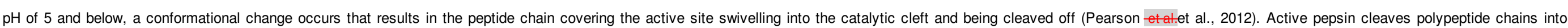

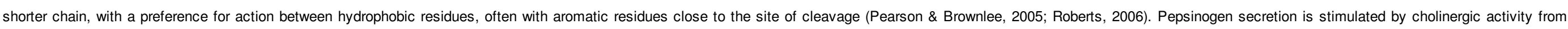
vagal afferents and a range of other neurohumoral mediators, as a result of intake of food (Fiorucci et al., 2003; Pearson \& Brownlee, 2005).

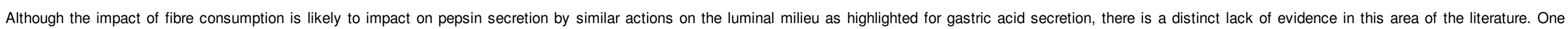

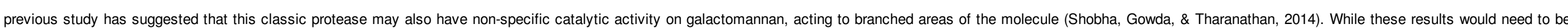

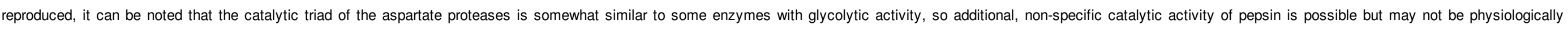
relevant.

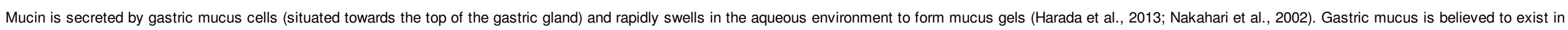

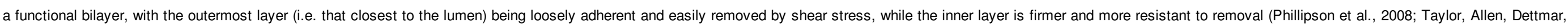

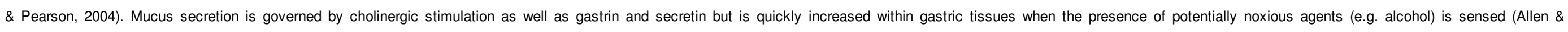
Flemström, 2005).

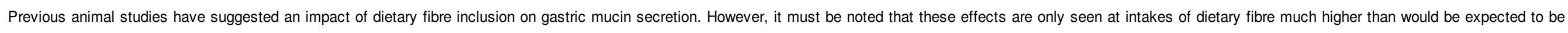

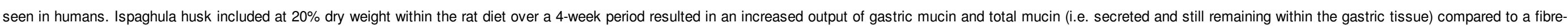

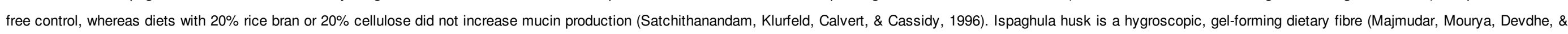

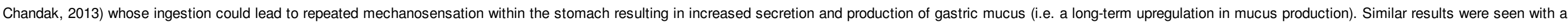

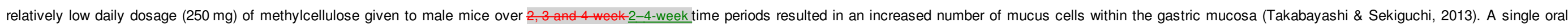

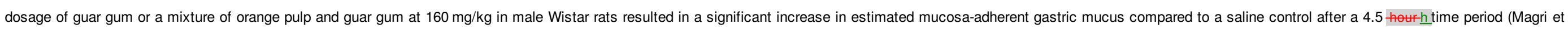

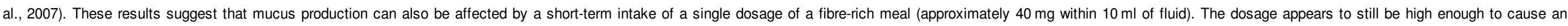
increased viscosity of stomach contents within an average male rat and therefore suggests that mechanical stimulation of the stomach also leads to an immediate effect on mucus secretion. 


\section{elsevier_BCDF_68}

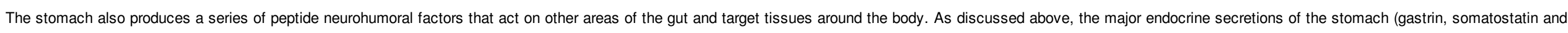

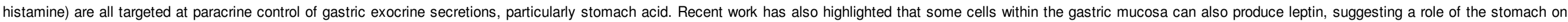

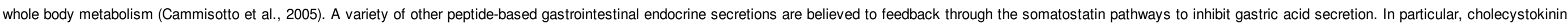
and gastric inhibitory peptide (released by the duodenal I and $\mathrm{K}$ eellscells, respectively) are believed to be of major importance in this mechanism (Schubert \& Peura, 2008).

\section{Dietary fibre and diseases of the oropharynx, oesophagus and stomach}

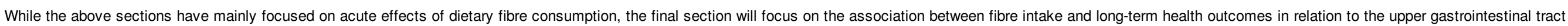

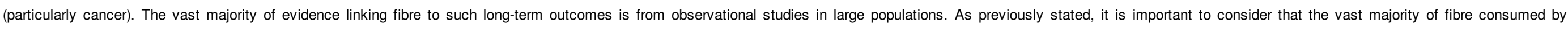

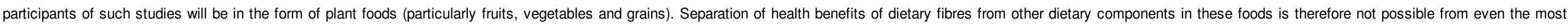

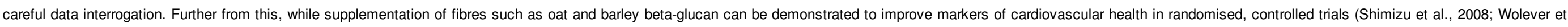

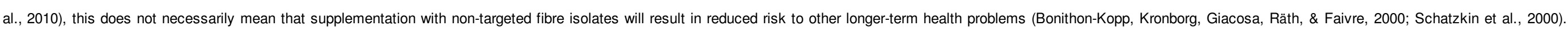

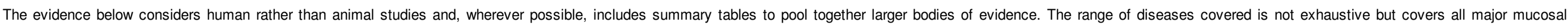
diseases of the upper gastrointestinal tract.

\section{Oropharyngeal conditions}

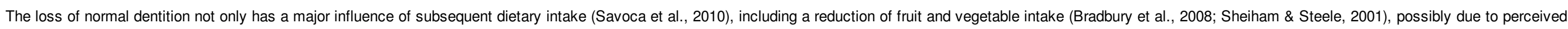

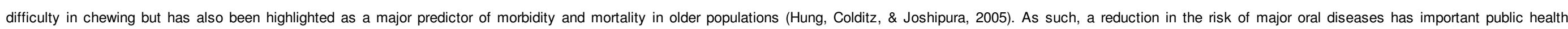

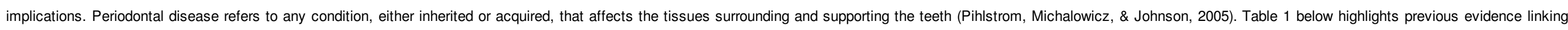

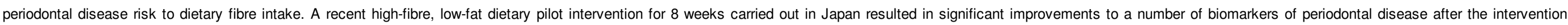
period. Biomarker values returned to baseline 24 weeks after the intervention had finished (Kondo et al., 2014).

Table 1 Dietary fibre and observational risk of oral conditions and head and neck cancers.

\begin{tabular}{|c|c|c|c|c|}
\hline Disease/condition & Study design & Comparative statistics $(95 \% \mathrm{Cl})$ & Notes & Reference \\
\hline \multirow[t]{2}{*}{ Periodontal disease } & $\begin{array}{l}\text { Prospective follow-up periodontal } \\
\text { disease progression in } 625 \\
\text { community-dwelling older men }\end{array}$ & $\begin{array}{l}\text { HR } 0.76(0.60-0.95) \text { per serving of high fibre foods/d for alveolar bone } \\
\text { loss and HR } 0.72(0.53-0.97) \text { for tooth loss }\end{array}$ & $\begin{array}{l}\text { Significantly lower HR in individuals over } 65 \text { years of } \\
\text { age only }\end{array}$ & $\begin{array}{l}\text { Schwartz, Kaye, Nunn, } \\
\text { Spiro lii and Garcia } \\
\text { (2012) }\end{array}$ \\
\hline & $\begin{array}{l}\text { Prospective follow-up of } 34,160 \\
\text { males for periodontal disease }\end{array}$ & $\begin{array}{l}\text { RR } 0.77(0.66,0.89) \text { for highest vs } 1 \text { (lowest) intake of whole grain } \\
\text { intake quintile }\end{array}$ & $\begin{array}{l}\text { No significant association for vegetable and fruit fibre } \\
\text { intake with disease risk }\end{array}$ & $\begin{array}{l}\text { Merchant, Pitiphat, } \\
\text { Franz, and Joshipura } \\
\text { (2006) }\end{array}$ \\
\hline \multirow[t]{5}{*}{ Oropharngeal cancer } & $\begin{array}{l}\text { Case-control study with } 804 \text { cases of } \\
\text { oral cancer }\end{array}$ & $\begin{array}{l}\text { OR } 0.47 \text { (0.34-0.65) for highest vs } 1 \text { (lowest) quintile of fit for dietary } \\
\text { pattern "Vitamins and fiber" }\end{array}$ & $\begin{array}{l}\text { Animal products (positively) and unsaturated fats } \\
\text { (negatively) patterns also associated with risk }\end{array}$ & Edefonti et al. (2010) \\
\hline & $\begin{array}{l}\text { Case-control study with } 598 \text { cases of } \\
\text { oral and pharyngeal cancer }\end{array}$ & $\begin{array}{l}\text { RR } 0.40(0.26-0.62) \text { for }>6 \text { characteristics of the Mediterranean diet vs } \\
<3(\mathrm{RR}=1)\end{array}$ & $\begin{array}{l}\text { A total of } 8 \text { characteristics of the Mediterranean diet } \\
\text { template were considered }\end{array}$ & Bosetti et al. (2003) \\
\hline & $\begin{array}{l}\text { Case-control study with } 524 \text { cases of } \\
\text { oral and pharyngeal cancer }\end{array}$ & $\begin{array}{l}\text { OR } 0.3(0.1,0.4) \text { for intake of whole grains }>3 \mathrm{~d} / \mathrm{wk} \text { versus no or rare } \\
\text { consumption of whole grains }(\mathrm{OR}=1)\end{array}$ & & $\begin{array}{l}\text { La Vecchia, } \\
\text { Chatenoud, Negri, and } \\
\text { Franceschi (2003) }\end{array}$ \\
\hline & $\begin{array}{l}\text { Case-control study with } 232 \text { cases of } \\
\text { pharyngeal cancer }\end{array}$ & $\begin{array}{l}\text { OR } 1.6(1.3-10.1) \text { for no intake of "Dietary fiber-containing food" vs } 1 \\
\text { for some intake. OR } 3.80 \text { (1.58-9.12) for very low intake of "Uncooked } \\
\text { vegetables" vs } 1 \text { for higher intake }\end{array}$ & $\begin{array}{l}\text { "Dietary fiber-containing foods" defined as legumes and } \\
\text { cereals except for wheat bread. Very low intake defined } \\
\text { as } 1 \text { to } 3 \text { times per month }\end{array}$ & $\begin{array}{l}\text { Escribano Uzcudun et } \\
\text { al. (2002) }\end{array}$ \\
\hline & Case-control study with 485 cases of & OR $0.96(0.94,0.99)$ for highest quartile of total dietary fibre intake vs 1 & & Hebert et al. (2002) \\
\hline
\end{tabular}

Case-control study with 485 cases of OR $0.96(0.94,0.99)$ for highest quartile of total dietary fibre intake vs 1 


\begin{tabular}{|c|c|c|c|c|}
\hline & $\begin{array}{l}\text { precancerous oral lesions in "reverse- } \\
\text { smoking" females }\end{array}$ & (lowest quartile) & & \\
\hline $\begin{array}{l}\text { Disease/eonditionstudly } \\
\text { designGomparative statisties } 195 \% \\
\text { El)NotesRefonceOropharngeal cancer } \\
\text { (cont.) }\end{array}$ & $\begin{array}{l}\text { Case-control study with } 598 \text { cases of } \\
\text { oropharyngeal cancer }\end{array}$ & $\begin{array}{l}\text { Continuous } O R \text { of } 0.51(0.40-0.66) \text { for highest quintiles of total fibre } \\
\text { intake versus lowest }(O R=1)\end{array}$ & & Soler et al. (2001) \\
\hline \multirow[t]{3}{*}{ Head and neck cancers } & $\begin{array}{l}\text { Pooled analysis of } 61,647 \text { adults } \\
\text { following different habitual diets }\end{array}$ & $\begin{array}{l}\text { RR } 0.94(0.62,1.43) \text { vegetarians and vegans versus } 1 \text { for meat eaters } \\
\text { for "upper Gl cancer" }\end{array}$ & $\begin{array}{l}\text { Upper GI cancer defined as malignant neoplasms of lip, } \\
\text { oral cavity, pharynx and oesophagus }\end{array}$ & $\begin{array}{l}\text { Key, Appleby, Crowe, } \\
\text { Bradbury, Schmidt, and } \\
\text { Travis (2014) }\end{array}$ \\
\hline & $\begin{array}{l}\text { Case-control study with } 2452 \text { case of } \\
\text { head and neck cancer }\end{array}$ & $\begin{array}{l}\text { OR } 0.56(0.45-0.69) \text { for highest vs } 1 \text { (lowest) quintile of fit for dietary } \\
\text { pattern "Antioxidant vitamins and fiber" }\end{array}$ & $\begin{array}{l}\text { Included oral, pharyngeal and laryngeal cancer cases. } \\
\text { Negative association between fit to "Fats" pattern and } \\
\text { OR }\end{array}$ & Edefonti et al. (2012) \\
\hline & $\begin{array}{l}\text { Prospective, } 11 \text {-y follow-up in } \\
494,991 \text { participants }\end{array}$ & $\begin{array}{l}\text { HR } 0.61(0.42-0.89) \text { highest total fibre intake vs } 1 \text { (lowest intake) in } \\
\text { women }\end{array}$ & $\begin{array}{l}\text { No significant trend for association of total fibre and HR } \\
\text { in men. Risk of head and neck (oral, pharyngeal and } \\
\text { laryngeal) cancers assessed }\end{array}$ & Lam et al. (2011) \\
\hline
\end{tabular}

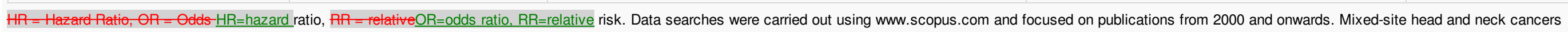
(many of which are oropharyngeal) were also included within this literature research strategy.

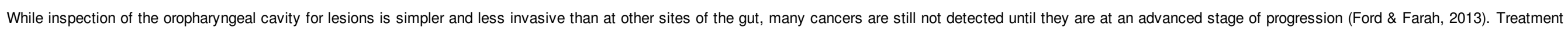

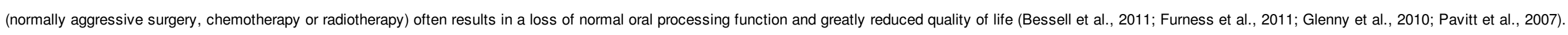

\section{Diseases of the oesophagus and stomach}

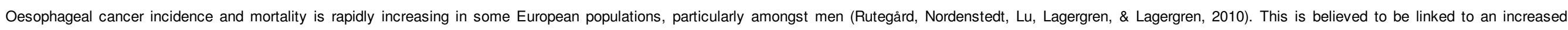

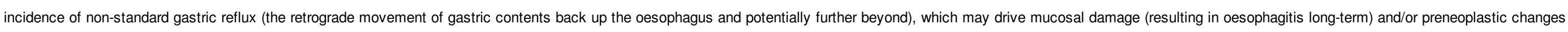

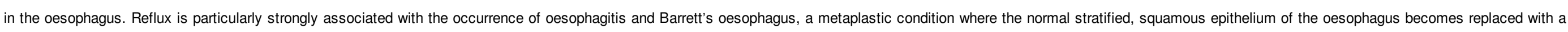

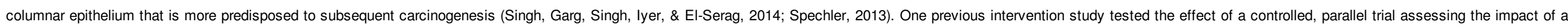

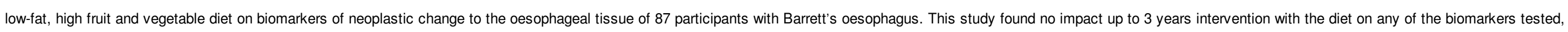

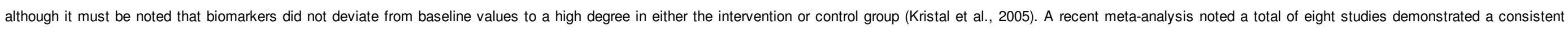

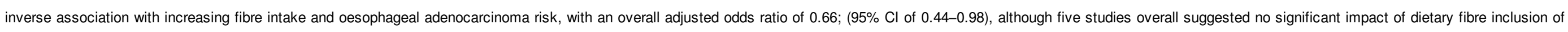
squamous cell carcinoma. Two further studies also suggested a significant inverse with increasing fibre intake and Barrett's oesophagus risk (Coleman et al., 2013).

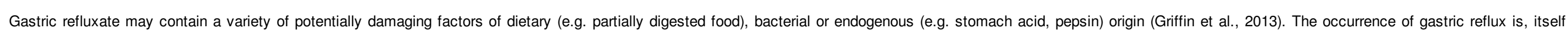

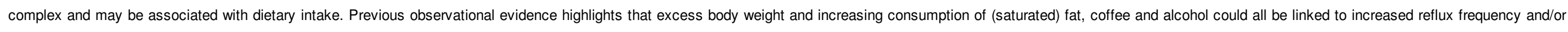

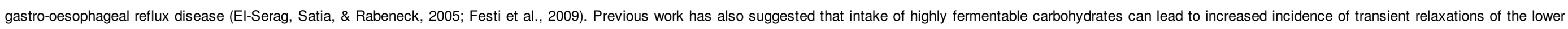

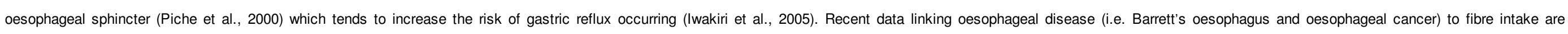
highlighted in Table 2.

Table 2 Summary of associative studies linking dietary fibre intake and observational risk of oesophageal and gastric conditions.

\begin{tabular}{|c|c|c|c|c|}
\hline Disease/condition & Study design & Comparative statistics $(95 \% \mathrm{Cl})$ & Notes & Reference \\
\hline Oesophagitis & $\begin{array}{l}\text { Case-control study with } 219 \text { cases of reflux } \\
\text { oesophagus }\end{array}$ & $\begin{array}{l}\text { Adjusted OR } 0.71(0.32-1.60) \text { for }>19.1 \mathrm{~g} \\
\text { Englyst fibre/d vs } 1 \text { for }<14.3 \mathrm{~g} / \mathrm{d}\end{array}$ & & Mulholland et al. (2009) \\
\hline
\end{tabular}




\section{elsevier_BCDF_68}

\begin{tabular}{|c|c|c|c|c|}
\hline \multirow[t]{3}{*}{$\begin{array}{l}\text { Barrett's } \\
\text { oesophagus }\end{array}$} & $\begin{array}{l}\text { Case-control study with } 304 \text { cases of } \\
\text { Barrett's oesophagus }\end{array}$ & $\begin{array}{l}\text { Adjusted OR } 0.50(0.28-0.90) \text { for total dietary } \\
\text { fibre }>8.9 \mathrm{~g} / \mathrm{d} \text { vs } 1 \text { for }<6.8 \mathrm{~g} / \mathrm{d}\end{array}$ & $\begin{array}{l}\text { Increasing legume and green leafy vegetable intake was associated with reduced risk } \\
\text { whereas total vegetable and fruit intakes were not }\end{array}$ & Jiao et al. (2013) \\
\hline & $\begin{array}{l}\text { Case-control study with } 220 \text { cases of long- } \\
\text { segment Barrett's oesophagus }\end{array}$ & $\begin{array}{l}\text { Adjusted OR } 0.40(0.22-0.73) \text { for }>17.7 \mathrm{~g} \\
\text { Englyst fibre/d vs } 1 \text { for }<13.7 \mathrm{~g} / \mathrm{d}\end{array}$ & & Mulholland et al. (2009) \\
\hline & $\begin{array}{l}\text { Case-control study with } 296 \text { cases of } \\
\text { Barrett's oesophagus }\end{array}$ & $\begin{array}{l}\text { OR } 0.34(0.15-0.76) \text { for highest quartile of total } \\
\text { fibre intake vs } 1 \text { for lowest quartile of intake }\end{array}$ & $\begin{array}{l}\text { Cases were matched to "controls" with gastro-oesophageal reflux disease. Fibre from } \\
\text { fruits and vegetables was significantly associated with reduced risk while fibre from grains } \\
\text { and beans was not }\end{array}$ & $\begin{array}{l}\text { Kubo, Block, Quesenberry, } \\
\text { Buffler and Corley (2009) }\end{array}$ \\
\hline \multirow[t]{3}{*}{$\begin{array}{l}\text { Oesophageal } \\
\text { cancer }\end{array}$} & $\begin{array}{l}\text { Case-control study with } 47 \text { cases of } \\
\text { oesophageal squamous cell carcinoma }\end{array}$ & $\begin{array}{l}\text { Adjusted OR } 0.30(0.15-0.78) \text { for highest tertile } \\
\text { of fibre intake vs } 1 \text { for lowest }\end{array}$ & Lower glycaemic index and glycaemic load were also associated with lower OR & $\begin{array}{l}\text { Eslamian, Jessri, } \\
\text { Hajizadeh, Ibiebele, and } \\
\text { Rashidkhani (2013) }\end{array}$ \\
\hline & $\begin{array}{l}\text { Case-control study with } 359 \text { cases of } \\
\text { oesophageal cancer }\end{array}$ & $\begin{array}{l}\text { Adjusted OR } 0.47(0.32,0.69) \text { for }>27 \mathrm{~g} / \mathrm{d} \text { total } \\
\text { dietary fibre versus } 1 \text { for }<16 \mathrm{~g} / \mathrm{d}\end{array}$ & & $\begin{array}{l}\text { Tang, Xu, Zhang, Lei, } \\
\text { Binns, and Lee (2013) }\end{array}$ \\
\hline & $\begin{array}{l}\text { Case-control study with } 224 \text { cases of } \\
\text { oesophageal adenocarcinoma }\end{array}$ & $\begin{array}{l}\text { Adjusted OR } 0.79(0.43-1.44) \text { for }>17.7 \mathrm{~g} \\
\text { Englyst fibre/d vs } 1 \text { for }<13.7 \mathrm{~g} / \mathrm{d}\end{array}$ & & Mulholland et al. (2009) \\
\hline \multirow[t]{8}{*}{$\begin{array}{l}\text { Oesophageal } \\
\text { cancer (cont) }\end{array}$} & $\begin{array}{l}\text { Case-control study with } 206 \text { cases of } \\
\text { oesophageal adenocarcinoma }\end{array}$ & $\begin{array}{l}\text { Adjusted OR } 0.44(0.3-0.8) \text { for highest quartile } \\
\text { of fibre intake vs } 1 \text { for lowest }\end{array}$ & & $\begin{array}{l}\text { Wu, Tseng, Hankin, and } \\
\text { Bernstein (2007) }\end{array}$ \\
\hline & $\begin{array}{l}\text { Case-control study with } 304 \text { cases of } \\
\text { oesophageal cancer }\end{array}$ & $\begin{array}{l}\mathrm{RR} 0.23(95 \% \mathrm{Cl}, 0.13-0.40) \text { for }>6 \\
\text { characteristics of the Mediterranean diet vs }<3 \\
\text { (RR=1) }\end{array}$ & A total of 8 characteristics of the Mediterranean diet template were considered & Bosetti et al. (2003) \\
\hline & $\begin{array}{l}\text { Case-control study with } 124 \text { cases of } \\
\text { oesophageal adenocarcinoma }\end{array}$ & $\begin{array}{l}\text { Adjusted OR } 0.5(0.3-0.9) \text { for highest quartile of } \\
\text { total fibre intake vs } 1 \text { for lowest }\end{array}$ & & Chen et al. (2002) \\
\hline & $\begin{array}{l}\text { Case-control study with } 304 \text { cases of } \\
\text { oesophageal cancer }\end{array}$ & $\begin{array}{l}\text { Continuous } O R \text { of } 0.70(0.51-0.96) \text { for highest } \\
\text { quintiles of total fibre intake versus lowest } \\
(\mathrm{OR}=1)\end{array}$ & & Soler et al. (2001) \\
\hline & $\begin{array}{l}\text { Case-control study with } 189 \text { cases of } \\
\text { oesophageal }\end{array}$ & $\begin{array}{l}\text { Adenocarcinoma: Adjusted OR } 0.8(0.5-1.3) \text { for } \\
\text { highest quartile of total fibre intake vs } 1 \text { for } \\
\text { lowest }\end{array}$ & & $\begin{array}{l}\text { Terry, Lagergren, Ye, Wolk, } \\
\text { and Nyrén (2001) }\end{array}$ \\
\hline & $\begin{array}{l}\text { adenocarcinoma and } 167 \text { cases of } \\
\text { oesophageal squamous cell carcinoma }\end{array}$ & $\begin{array}{l}\text { Squamous carcinoma: Adjusted OR } 1.1 \\
(0.6-1.9) \text { for highest quartile of total fibre intake } \\
\text { vs } 1 \text { for lowest }\end{array}$ & & \\
\hline & $\begin{array}{l}\text { Case-control study with } 282 \text { cases of } \\
\text { adenocarcinoma and } 206 \text { cases of } \\
\text { squamous cell carcinoma }\end{array}$ & $\begin{array}{l}\text { Adenocarcinoma: Adjusted OR } 0.28(0.19-0.40) \\
\text { for highest quartile of total fibre intake vs } 1 \text { for } \\
\text { lowest }\end{array}$ & $\begin{array}{l}\text { Similarly significant effects of inclusion of soluble and insoluble fibre noted, as well as } \\
\text { fibre intake/kJ }\end{array}$ & Mayne et al. (2001) \\
\hline & & $\begin{array}{l}\text { Squamous carcinoma: Adjusted OR } 0.24 \\
(0.14-0.38) \text { for highest quartile of total fibre } \\
\text { intake vs } 1 \text { for lowest }\end{array}$ & & \\
\hline
\end{tabular}

DiseaseleonditionStudy designComparative statistics (95\% CI)NotesReference

\section{Disease/eonditionstudy \\ designComparative statisties $195 \%$ \\ CIN NotesReferenceGastric cancer}

Pooled analysis of 61,647 adults following different habitual diets

Case-control study with 256 cases of gastric
RR $0.37(0.19,0.69)$ for vegetarians and vegans versus 1 for meat eaters for stomach cancer

Cardia: Adjusted OR $0.58(0.4-0.9)$ for highest
Key -et al.et al. (2014)

Wu et al.et al. (2007) 


\section{elsevier_BCDF_68}

cardia and 366 distal cases of gastric adenocarcinoma

Case-control study with 300 cases of dista gastric adenocarcinoma
Distal: Adjusted OR 0.69 (0.5-1.0) for highest quartile of fibre intake vs 1 for lowest

Men: Adjusted OR 0.4 (0.3-0.7) for highest tertile of total non-starch polysaccharide intake vs 1 for lowest

Women: Adjusted $0.5(0.3-1.0)$ for highest tertile of total total non-starch polysaccharide intake vs of total total
1 for lowest

Case-control study with 124 cases of distal gastric cancer

Adjusted $0.4(0.2-0.8)$ for highest quartile of total fibre intake vs 1 for lowest

Adjusted OR $0.4(0.3-0.8)$ for highest quartile of total fibre intake vs 1 for lowest

Case-control study with 262 cases of gastric cardia adenocarcinoma

Cardia: Adjusted OR $0.43(0.30-0.61)$ for highest quartile of total fibre intake vs 1 for lowest

Case-control study with 255 cases of gastric cardia adenocarcinoma and 352 cases of noncardia cancer

\section{Non-cardia: Adjusted OR 0.38 (0.28-0.53) for highest quartile of total fibre intake vs 1 for}

lowest

Follow-up cohort study on gastric carcinoma for 6.3 years in 120,852 participants aged

55-69
Adjusted RR $0.8(0.6-1.2)$ for highest quintile of total fibre intake vs 1 for lowest

of

Total, soluble and insoluble non-starch polysaccharides also
did not significantly correlate with subsequent gastric
carcinoma occurrence
Nomura, Hankin, Kolonel, Wilkens, Goodman, and Stemmermann (2003)

Chen et al. (2002)

Increased cereal and vegetable (but not fruit) fibre intakes were associated with reduced OR

Terry et al.et al. (2001)

Similarly significant effects of inclusion of soluble and insoluble fibre noted, as well as fibre intake/k

Mayne et al. (2001)

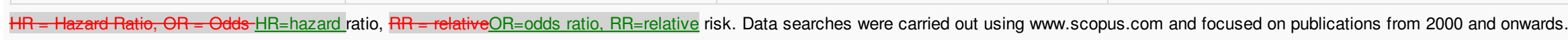

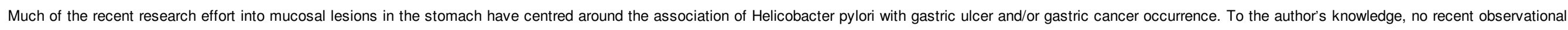

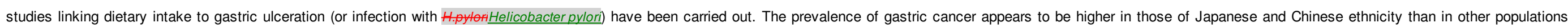

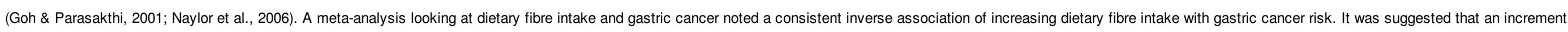

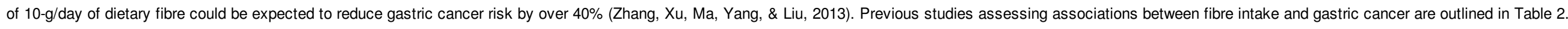

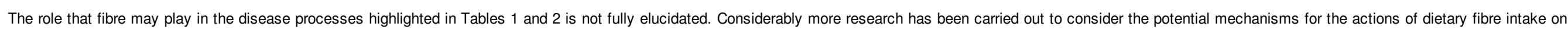

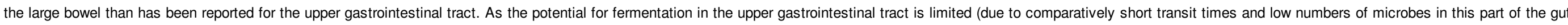

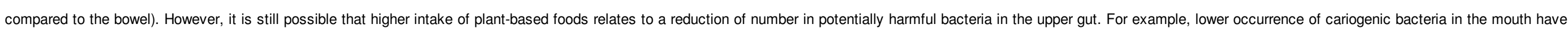

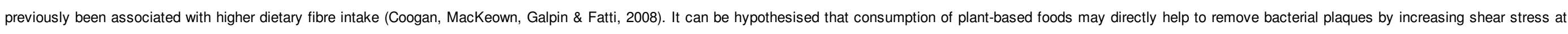
the surface of teeth, or indirectly reduce bacterial numbers by increasing salivary flow (resulting in an increased output of bacteriocidalbactericidal factors).

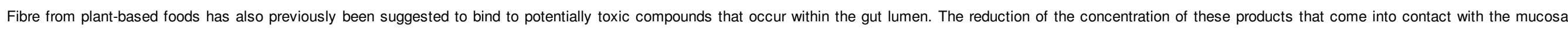

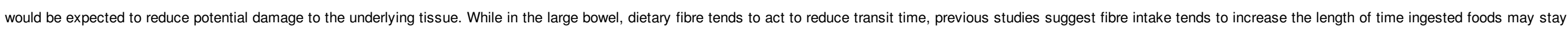

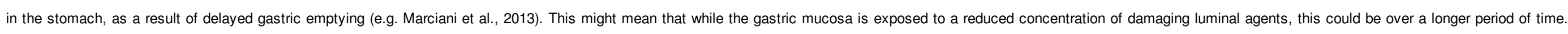

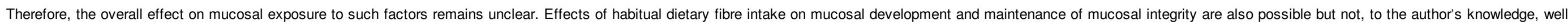
studied in the upper GI tract.

\section{Summary}




\section{elsevier_BCDF_68}

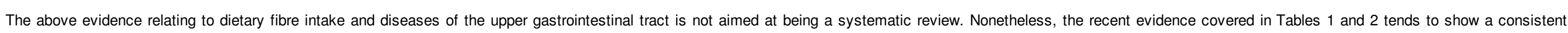

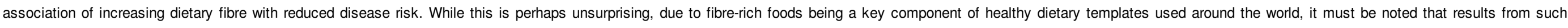

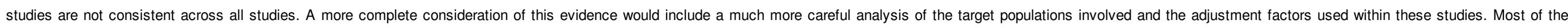
current evidence in this area comes from case-controlled studies, suggesting the need a range of prospective cohort studies in the future.

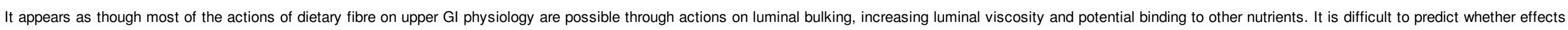

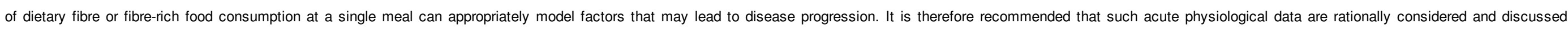

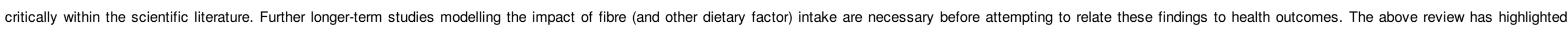

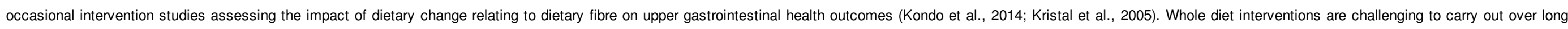

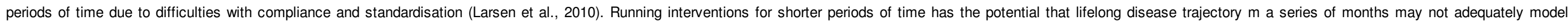

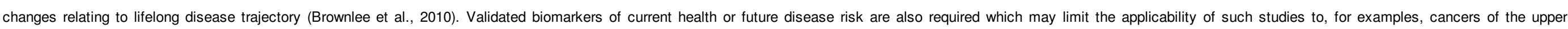

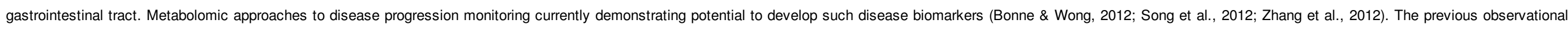

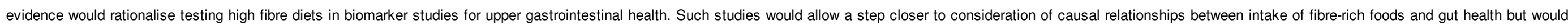

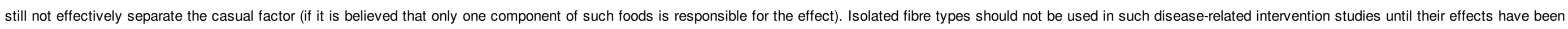
appropriately modelled in laboratory studies and acute physiological experiments with human participants.

\section{Acknowledgements}

IAB is fully employed as a lecturer by Newcastle University. This review was carried out as part of this job role. IAB's research currently receives funding from Cereal Partners Worldwide.

\section{References}

Akiba Y. and Kaunitz J.D., Duodenal luminal chemosensing; acid, ATP, and nutrients, Current Pharmaceutical Design 2020 (16), 2014, $2760-2765$.

Allen A. and Flemström G., Gastroduodenal mucus bicarbonate barrier: Protection against acid and pepsin, American Journal of Physiology CelfPhysiology-Cell Physiology 288288 (1 57-1), 2005, C1-C19.

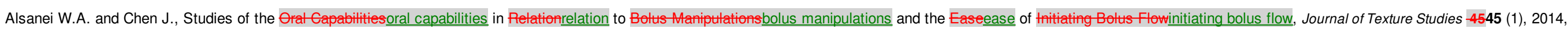
$1-12$.

Azpiroz F., Feinle-Bisset C., Grundy D. and Tack J., Gastric sensitivity and reflexes: Basic mechanisms underlying clinical problems, Journal of Gastroenterology -4949 (2), $2014,206-218$.

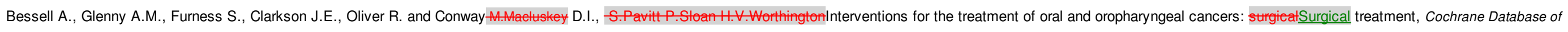
Systematic Reviews (Online) 2011, 99.

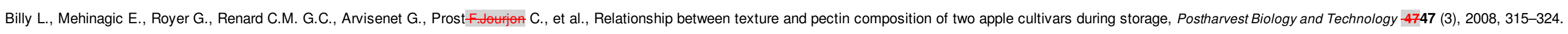

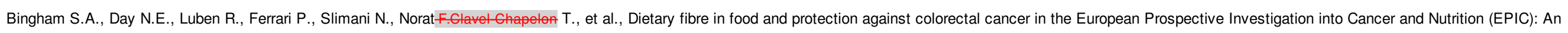
observational study, Lancet 361361 (9368), 2003, 1496-1501.

Blevins J.E. and Ho J.M., Role of oxytocin signaling in the regulation of body weight, Reviews in Endocrine and Metabolic Disorders 1414 (4), $2013,311-329$.

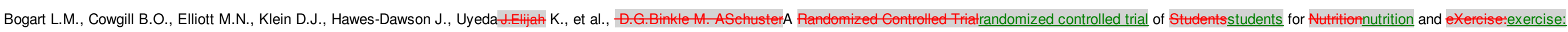
A Gommunity-Based Partieipatory Researeh Studycommunity-based participatory research study, Journal of Adolescont HealthJournal of Adolescent Health 2014.

Bolhuis D.P., Forde C.G., Cheng Y., Xu H., Martin N. and De Graaf C., Slow food: Sustained impact of harder foods on the reduction in energy intake over the course of the day, PLoS 9 NEOne 99 , 2014, 4.

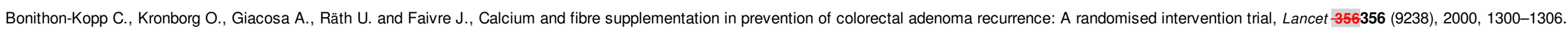




\section{elsevier_BCDF_68}

Bonne N.J. and Wong D.T. W., Salivary biomarker development using genomic, proteomic and metabolomic approaches, Genome Medicine -44, 2012, 10.

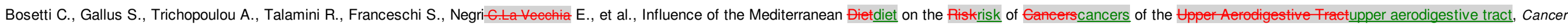
Epidemiology Biomarkers and Prevention 1212 (10), 2003, 1091-1094.

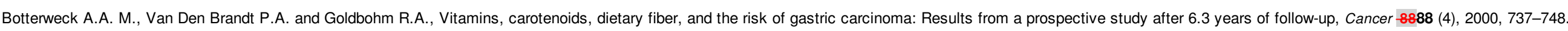

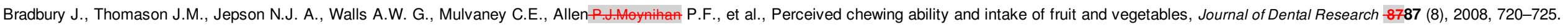

Brownlee I.A., The physiological roles of dietary fibre, Food Hydrocolloids 2525 (2), 2011, 238-250.

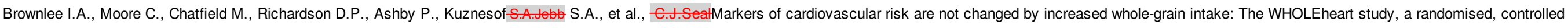
dietary intervention, British Journal of Nutrition 104104 (1), 2010, 125-134.

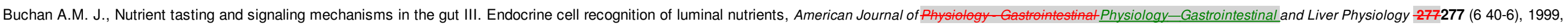
G1103-G1107.

Cammisotto P.G., Renaud C., Gingras D., Delvin E., Levy E. and Bendayan M., Endocrine and exocrine secretion of leptin by the gastric mucosa, Journal of Histochemistry and Cytochemistry 5353 (7), $2005,851-860$.

Chambers A.P., Sandoval D.A. and Seeley R.J., Integration of satiety signals by the central nervous system, Current Biology 2323 (9), 2013, R379-R388.

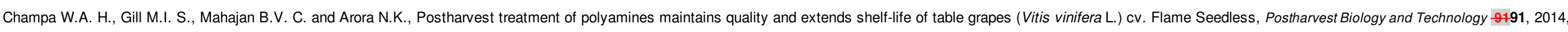
$57-63$.

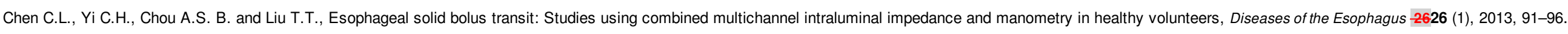

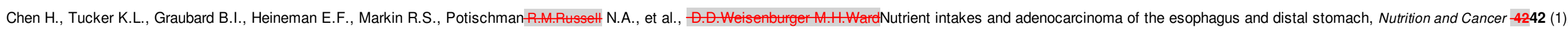
2002, 33-40.

Chen J., Food oral processing-Aprocessing_A review, Food Hydrocolloids 2323 (1), 2009, 1-25.

Chen J., Liu Z. and Prakash S., Lubrication studies of fluid food using a simple experimental set up, Food HydrocolloidsFood Hydrocolloids. 2014.

Cichero J.A. Y., Thickening agents used for dysphagia management: Effect on bioavailability of water, medication and feelings of satiety, Nutrition Journal 1212, 2013, 1.

Clark M.J. and Slavin J.L., The effect of fiber on satiety and food intake: aA systematic review, Journal of the American College of Nutrition 3232 (3), $2013,200-211$.

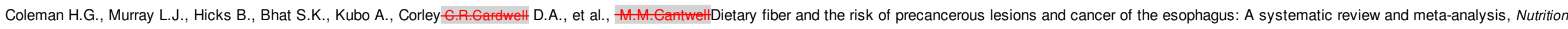

Reviews 7171 (7), 2013, 474-482.

Coogan M.M., MacKeown J.M., Galpin J.S. and Fatti L.P., Microbiological impressions of teeth, saliva and dietary fibre can predict caries activity, Journal of Dentistry 36 (11), 2008 , $892-899$.

Côté C.D., Zadeh-Tahmasebi M., Rasmussen B.A., Duca F.A. and Lam F.K.T.T.K. T., Hormonal signaling in the gut, Journal of Biological Chemistry 289 (17), $2014,11642-11649$.

De Graaf C., Blom W.A. M., Smeets P.A. M., Stafleu A. and Hendriks H.F. J., Biomarkers of satiation and satiety, American Journal of Clinical Nutrition 7979 (6), $2004,946-961$.

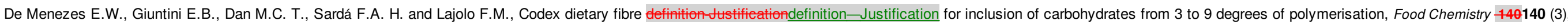
$2013,581-585$.

Depoortere I., Taste receptors of the gut: Emerging roles in health and disease, Gut 63 (1), 2014, 179-190.

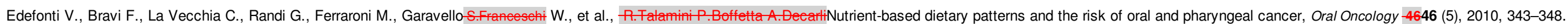




\section{elsevier_BCDF_68}

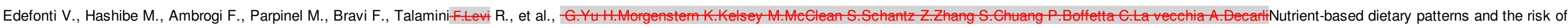
head and neck cancer: A pooled analysis in the International Head and Neck Cancer Epidemiology Consortium, Annals of Oncology 2323 (7), 2012, 1869-1880.

El-Serag H.B., Satia J.A. and Rabeneck L., Dietary intake and the risk of gastro-oesophageal reflux disease: A cross sectional study in volunteers, Gut 5454 (1), $2005,11-17$.

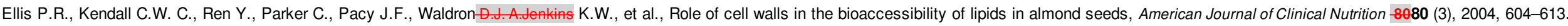

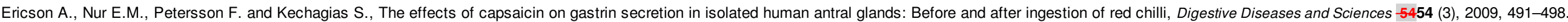

Ertekin C., Kiylioglu N., Tarlaci S., Turman A.B., Secil Y. and Aydogdu I., Voluntary and reflex influences on the initiation of swallowing reflex in man, Dysphagia 1616 (1), $2001,40-47$.

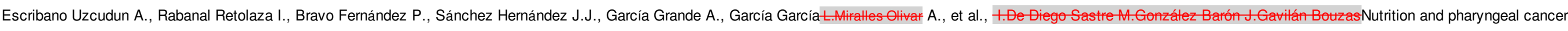
Results from a case-control study in Spain, Head and Neck 2424 (9), 2002, 830-840.

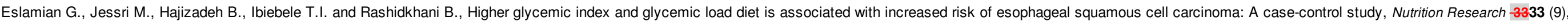
2013, 719-725.

European Heart Network, Diet, Physieal Aetivityphysical activity and Gardiovaseular Disease Preventioncardiovascular disease prevention in Eurepe. In)Europe, 2011, EHN; Brussels.

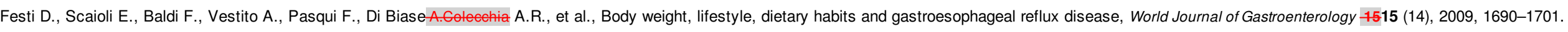

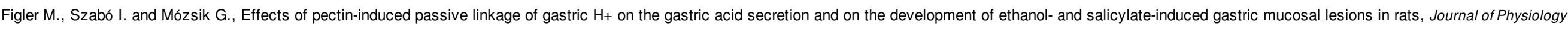
Paris 9393 (6), 1999, 495-499.

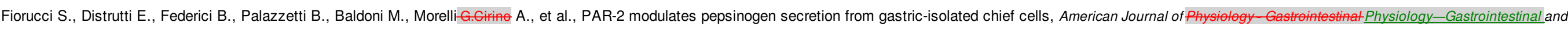
Liver Physiology 285285 (3 48-3), 2003, G611-G620.

Fiszman S. and Varela P., The role of gums in satiety/satiation. A review, Food Hydrocolloids 3232 (1), 2013, 147-154.

Fiszman S., Varela P., Díaz P., Linares M.B. and Garrido M.D., What is satiating? Consumer perceptions of satiating foods and expected satiety of protein-based meals, Food Research International $6262,2014,551-560$.

Flint H.J., The impact of nutrition on the human microbiome, Nutrition Reviews 7070 (SUPPLSUppl. 1), 2012, S10-S13.

Ford P.J. and Farah C.S., Early detection and diagnosis of oral cancer: Strategies for improvement, Journal of Cancer Policy 11 (4-21-2), 2013, e2-e7.

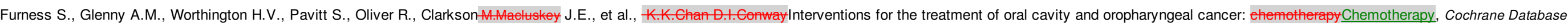
of Systematic Reviews (Online) 2011, -44.

Glenny A.M., Furness S., Worthington H.V., Conway D.I., Oliver R., ClarksonM.Macluskey J.E., et al., S.Pavitt K.K.Chan P.Broeklehurst G.E.PanetInterventions for the treatment of oral cavity and oropharyngeal cancer: radiotherapyRadiotherapy, Cochrane Database of Systematic reviews (Online) 2010, 1212.

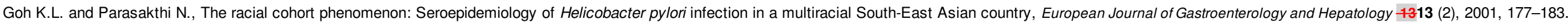

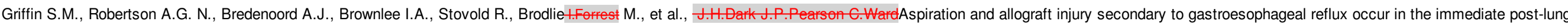
transplantation period (Prospective Clinical Trial), Annals of Surgery 258258 (5), 2013, 705-712.

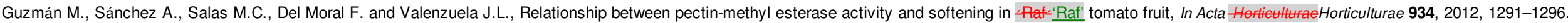

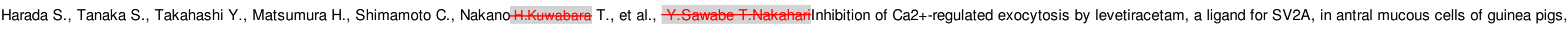

European Journal of Pharmacology 721721 (7-31-3), 2013, 185-192. 


\section{elsevier_BCDF_68}

Hayat J.O., Gabieta-Somnez S., Yazaki E., Kang J.Y., Woodcock A., Dettmar-Mabary P., et al., G.H.Knoles D.SifrimPepsin in saliva for the diagnosis of gastro-oesophageal reflux disease, Gut 2014.

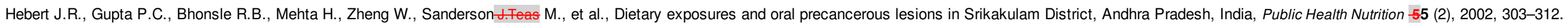

Hellström P.M., Grybäck P. and Jacobsson H., The physiology of gastric emptying, Best Practice and Research: Clinical Anaesthesiology 2020 (3), $2006,397-407$.

Herman R., Gao Y. and Storer N., Acid-induced unfolding kinetics in simulated gastric digestion of proteins, Regulatory Toxicology and Pharmacology -4646 (1), $2006,93-99$.

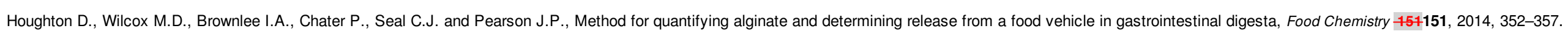

Howe G.R., Benito E., Castelleto R., Cornée J., Estève J., Gallagher-J.M.lseovich R.P., et al.,

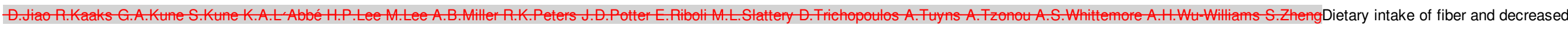
risk of cancers of the colon and rectum: Evidence from the combined analysis of 13 case-control studies, Journal of the National Cancer Institute 8484 (24), 1992, 1887-1895.

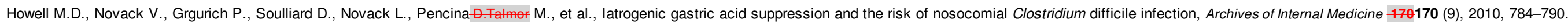
Hu F.B., Manson J.E., Stampfer M.J., Colditz G., Liu S., SolomonW.G.Willett C.G., et al., Diet, lifestyle, and the risk of type 2 diabetes mellitus in women, New England Journal of Medicine 345345 (11), $2001,790-797$.

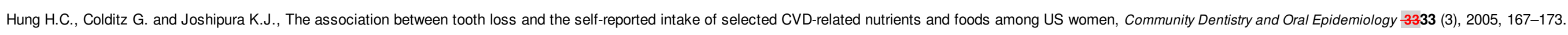
Inoue Y., Sasai M., Shiga S. and Moritaka H., Effects of gel amount and mastication on the velocity of agar and gelatin gels passing through the pharynx, Nippon Shokuhin Kagaku Kogaku Kaishi -5656 (5), 2009, $261-270$. Isackson H. and Ashley C.C., Secretory functions of the gastrointestinal tract, Surgery (United Kingdom) 3232 (8), 2014, 396-403.

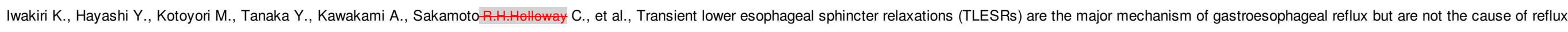
disease, Digestive Diseases and Sciences 5050 (6), 2005, 1072-1077.

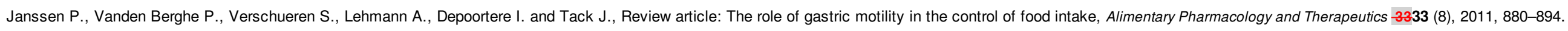

Janssen P., Verschueren S. and Tack J., Intragastric pressure as a determinant of food intake, Neurogastroenterology and Motility 2424 (7), 2012, 612, (e268).

Jarvis M.C., Plant cell walls: Supramolecular assemblies, Food Hydrocolloids 2525 (2), 2011, 257-262.

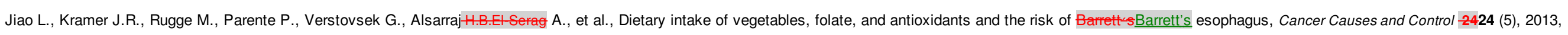
1005-1014.

Jolliffe D.M., Practical gastric physiology, Continuing Education in Anaesthesia, Critical Care and Pain 99 (6), 2009, 173-177.

Jones J.M., CODEX-aligned dietary fiber definitions help to bridge the ffiber gap'fiber gap', Nutrition Journal 1313, 2014, 1.

Kaoutari A.E., Armougom F., Gordon J.I., Raoult D. and Henrissat B., The abundance and variety of carbohydrate-active enzymes in the human gut microbiota, Nature Reviews Microbiology 1111 (7), $2013,497-504$.

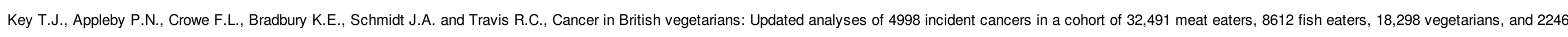
vegans, American Journal of Clinical Nutrition 100100 (SUPPL.SUppl. 1), 2014, 378S-385S.

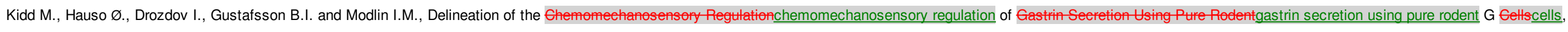
Gastroenterology 137 (1), 2009, 231-241, (e210).

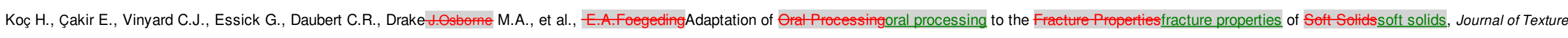
Studies -4545 (1), 2014, 47-61.

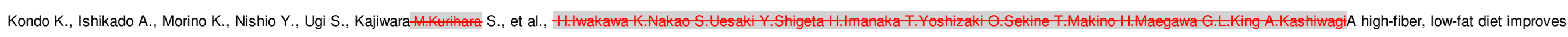




\section{elsevier_BCDF_68}

periodontal disease markers in high-risk subjects: A pilot study, Nutrition Research 3434 (6), 2014, 491-498.

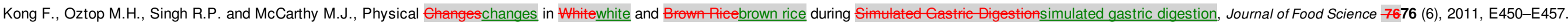
Kratz M., Baars T. and Guyenet S., The relationship between high-fat dairy consumption and obesity, cardiovascular, and metabolic disease, European Journal of Nutrition -5252 (1), $2013,1-24$.

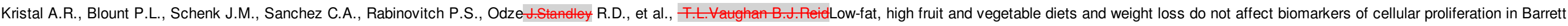
esophagus, Cancer Epidemiology Biomarkers and Prevention 1414 (10), 2005, 2377-2383.

Kubo A., Block G., Quesenberry C.P., Jr, Buffler P. and Corley D.A., Effects of dietary fiber, fats, and meat intakes on the risk of barrett‘sbarrett's esophagus, Nutrition and Cancer-6161 (5), 2009, 607-616.

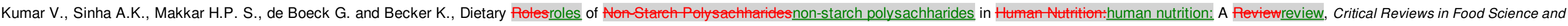
Nutrition 5252 (10), 2012, 899-935.

Kuznesof S., Brownlee I.A., Moore C., Richardson D.P., Jebb S.A. and Seal C.J., WHOLEheart study participant acceptance of wholegrain foods, Appetite -5959 (1), $2012,187-193$.

La Vecchia C., Chatenoud L., Negri E. and Franceschi S., Session: Whole cereal grains, fibre and human cancer wholegrain cereals and cancer in Italy, Proceedings of the Nutrition Society 6262 (1), $2003,45-49$.

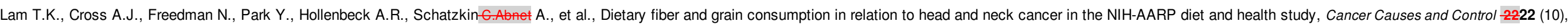
2011, 1405-1414.

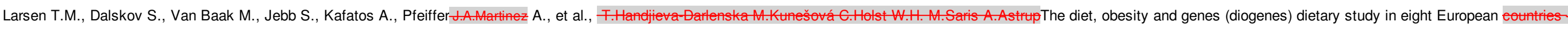
Acountries-A comprehensive design for long-term intervention, Obesity Reviews 1111 (1), 2010, 76-91.

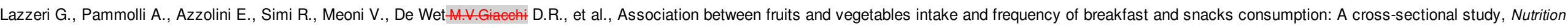
Journal 1212, 2013, 1

Le Révérend B.J. D., Edelson L.R. and Loret C., Anatomical, functional, physiological and behavioural aspects of the development of mastication in early childhood, British Journal of Nutrition 111111 (3), $2014,403-414$.

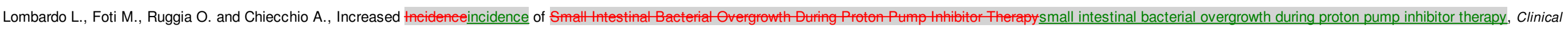
Gastroenterology and Hepatology 88 (6), 2010, 504-508.

Lund J.P. and Kolta A., Generation of the central masticatory pattern and its modification by sensory feedback, Dysphagia 2121 (3), 2006, 167-174.

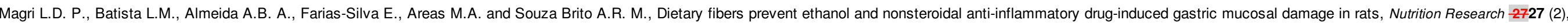
2007, 109-112.

Majmudar H., Mourya V., Devdhe S. and Chandak R., Pharmaceutical applications of Ispaghula Husk: Mucilage, International Journal of Pharmaceutical Sciences Review and Research 1818 (1), $2013,49-55$.

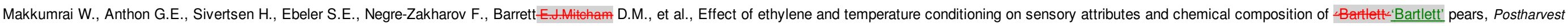
Biology and Technology 9797, 2014, 44-61.

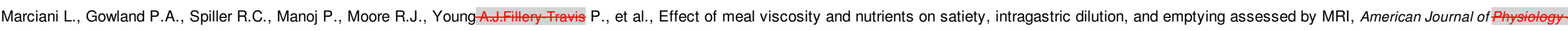
Gastrointestinat Physiology-Gastrointestinal and Liver Physiology 280280 (6 43-6), 2001, G1227-G1233.

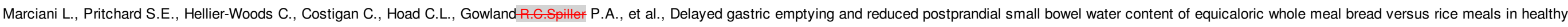
subjects: Novel MRI insights, European Journal of Clinical Nutrition -6767 (7), 2013, 754-758.

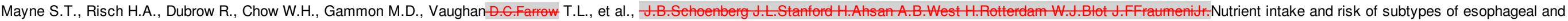
gastric cancer, Cancer Epidemiology Biomarkers and Prevention 1010 (10), 2001, 1055-1062. 


\section{elsevier_BCDF_68}

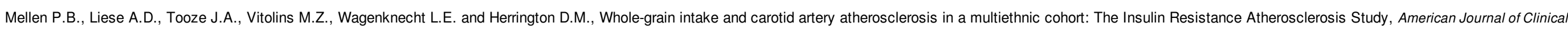
Nutrition 8585 (6), 2007, 1495-1502.

Merchant A.T., Pitiphat W., Franz M. and Joshipura K.J., Whole-grain and fiber intakes and periodontitis risk in men, American Journal of Clinical Nutrition -8383 (6), $2006,1395-1400$.

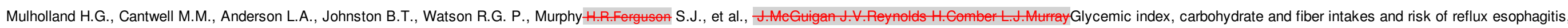
Barrett‘'sBarrett's esophagus, and esophageal adenocarcinoma, Cancer Causes and Control 2020 (3), 2009, 279-288.

Nakahari T., Fujiwara S., Shimamoto C., Kojima K., Katsu K.I. and Imai Y., cAMP modulation of Ca2+-regulated exocytosis in ACh-stimulated antral mucous cells of guinea pig, American Journal of Physiology Gastrointestinal Physiology_Gastrointestinal and Liver Physiology 282282 (5 45-5), 2002, G844-G856.

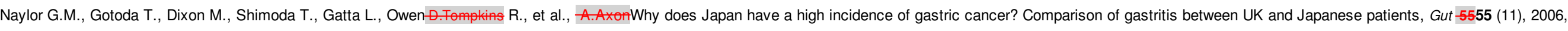
$1545-1552$.

Nishino T., The swallowing reflex and its significance as an airway defensive reflex, (Jan) JAANFrontiers in Physiology 33, 2013.

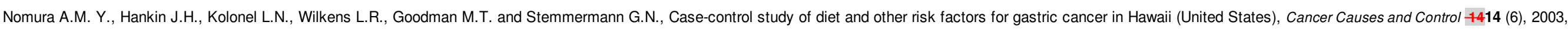
547-558.

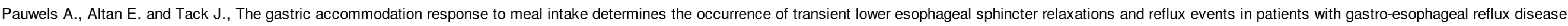
Neurogastroenterology and Motility 2626 (4), 2014, 581-588.

Pavitt S., Clarkson J.E., Conway D.I., Glenny A.M., Macluskey M., OliverP.Stoan R.J., et al.,

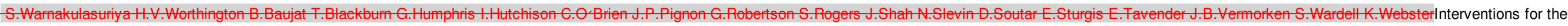
treatment of oral and oropharyngeal cancers: Immunotherapy/biotherapy, Cochrane Database of Systematic Reviews (4)), 2007.

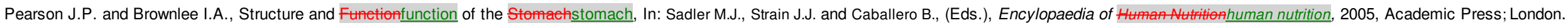

Pearson, J. P.. Parikh, S., Robertson, A. G. N., Stovold, R., \& Brownlee, I. A. (2012). Pepsins. In: Effects, diagnosis and management of extra-esophageal reflux. (pp. 29-41).

Pedersen A.M., Bardow A., Jensen S.B. and Nauntofte B., Saliva and gastrointestinal functions of taste, mastication, swallowing and digestion, Oral Diseases -88 (3), $2002,117-129$.

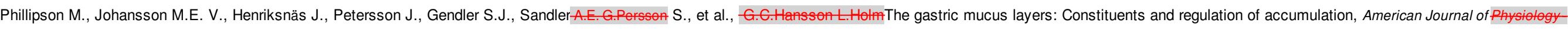
Gastrointestinat Physiology-Gastrointestinal and Liver Physiology 295295 (4), 2008, G806-G812.

Piche T., Zerbib F., Bruley Des Varannes S., Cherbut C., Anini Y., RozeA.Le Quellec C., et al., J.P.GalmieheModulation by colonic fermentation of LES function in humans, American Journal of Physiology Gastrointestinat Physiology-Gastrointestinal and Liver Physiology 278278 (4 41-4), 2000, G578-G584.

Pihlstrom B.L., Michalowicz B.S. and Johnson N.W., Periodontal diseases, Lancet 366366 (9499), 2005, 1809-1820.

Popa Nita S., Murith M., Chisholm H. and Engmann J., Matching the rheological properties of videofluoroscopic contrast agents and thickened liquid prescriptions, Dysphagia 2828 (2), $2013,245-252$.

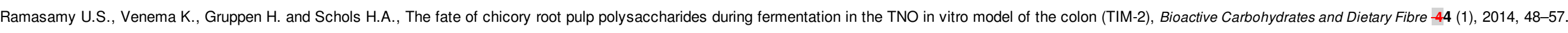

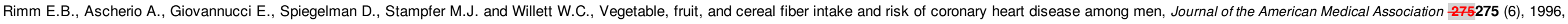
447-451.

Roberts N.B., Review article: Human pepsins-Theirpepsins-Their multiplicity, function and role in reflux disease, Alimentary Pharmacology and Therapeutics 2424 (SUPPL.Suppl. 2), $2006,2-9$.

Rutegård M., Nordenstedt H., Lu Y., Lagergren J. and Lagergren P., Sex-specific exposure prevalence of established risk factors for oesophageal adenocarcinoma, British Journal of Cancer 103103 (5), $2010,735-740$. 


\section{elsevier_BCDF_68}

Saqui-Salces M., Dowdle W.E., Reiter J.F. and Merchant J.L., A high-fat diet regulates gastrin and acid secretion through primary cilia, FASEB Journal 2626 (8), $2012,3127-3139$. Satchithanandam S., Klurfeld D.M., Calvert R.J. and Cassidy M.M., Effects of dietary fibers on gastrointestinal mucin in rats, Nutrition Research 1616 (7), $1996,1163-1177$.

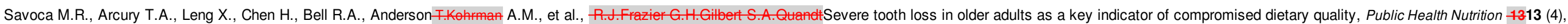
2010, 466-474.

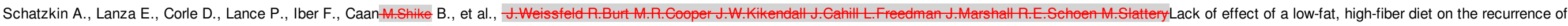
colorectal adenomas, New England Journal of Medicine 342342 (16), 2000, 1149-1155.

Schubert M.L. and Peura D.A., Control of Gastric Aeid Seeretiongastric acid secretion in Healthhealth and Diseasedisease, Gastroenterology 134134 (7), 2008, 1842-1860.

Schulz B.L., Cooper-White J. and Punyadeera C.K., Saliva proteome research: Current status and future outlook, Critical Reviews in Biotechnology 3333 (3), 2013, 246-259.

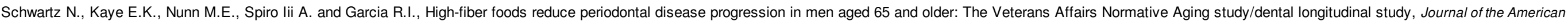
Geriatrics Society 6060 (4), 2012, 676-683.

Shafik A., El Sibai O., Shafik A.A. and Shafik I.A., Mechanism of gastric emptying through the pyloric sphincter: A human study, Medical Science Monitor 1313 (1), 2007, CR24-CR29.

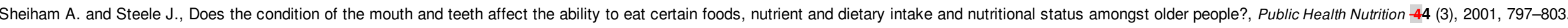

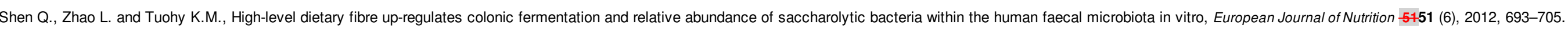

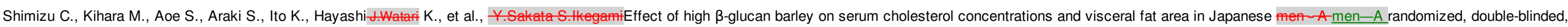
placebo-controlled trial, Plant Foods for Human Nutrition -6363 (1), 2008, $21-25$.

Shobha M.S., Gowda L.R. and Tharanathan R.N., A novel catalysis by porcine pepsin in debranching guar galactomannan, Carbohydrate Polymers 102102 (1), $2014,615-621$.

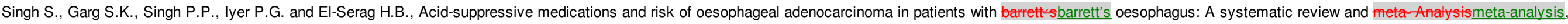
Gut 6363 (8), 2014, 1229-1237.

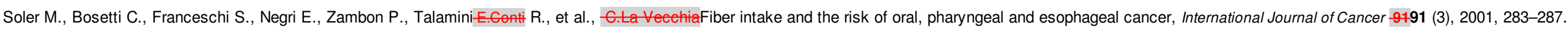

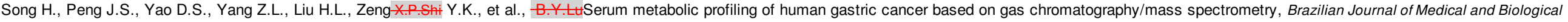
Research -4545 (1), 2012, 78-85.

Spechler S.J., Barrett esophagus and risk of esophageal cancer: A clinical review, JAMA-JournatJAMA-Journal of the American Medical Association 310310 (6), 2013, 627-636.

Steele C.M. and Van Lieshout P.H. H.M., Influence of bolus consistency on lingual behaviors in sequential swallowing, Dysphagia 1919 (3), 2004, 192-206.

Sworn, G., Kerdavid, E., \& Fayos, J. (2008). The role of hydrocolloids in the management of dysphagia. In: Gums and stabilisers for the food industry 14, (pp. 392-401).

Takabayashi F. and Sekiguchi H., Viscous methyl cellulose solution thickens gastric mucosa and increases the number of gland mucous cells in mice, British Journal of Nutrition 110110 (7), 2013, 1195-1200.

Tang L., Xu F., Zhang T., Lei J., Binns C.W. and Lee A.H., Dietary fibre intake associated with reduced risk of oesophageal cancer in Xinjiang, China, Cancer Epidemiology 3737 (6), 2013 , $893-896$.

Tarascou I., Souquet J.M., Mazauric J.P., Carrillo S., Coq S., CanonH.Futerand F., et al., V.CheynierThe hidden face of food phenolic composition, Archives of Biochemistry and Biophysics 501501 (1), 2010, 16-22.

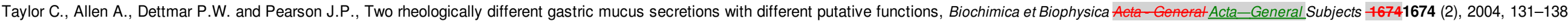
Terry P., Lagergren J., Ye W., Wolk A. and Nyrén O., Inverse association between intake of cereal fiber and risk of gastric cardia cancer, Gastroenterology 120120 (2), $2001,387-391$.

Torii K., Uneyama H. and Nakamura E., Physiological roles of dietary glutamate signaling via gut-brain axis due to efficient digestion and absorption, Journal of Gastroenterology -4848 (4), $2013,442-451$. 


\section{elsevier_BCDF_68}

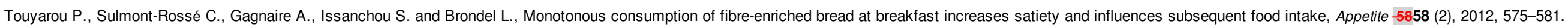

Van Daele D.J., Fazan V.P. S., Agassandian K. and Cassell M.D., Amygdala connections with jaw, tongue and laryngo-pharyngeal premotor neurons, Neuroscience 177177 (93-11393-113), 2011.

van der Bilt A., Engelen L., Pereira L.J., van der Glas H.W. and Abbink J.H., Oral physiology and mastication, Physiology and Behavior 8989 (1), $2006,22-27$.

Veeregowda D.H., Busscher H.J., Vissink A., Jager D.J., Sharma P.K. and van der Mei H.C., Role of structure and glycosylation of adsorbed protein films in biolubrication, PLoS ONEOne 77, $2012,8$.

Vijayvargiya P., Camilleri M., Shin A., Breen M. and Burton D., Simplifying the measurement of gastric accommodation using SPECT, Neurogastroenterology and Motility 2525 (6), $2013,542-546$.

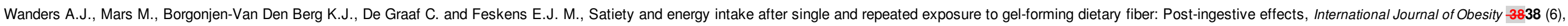
2014, 794-800.

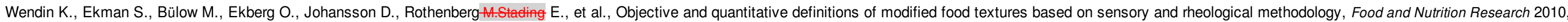
5454.

Wickham M.J. S., Faulks R.M., Mann J. and Mandalari G., The design, operation, and application of a dynamic gastric model, Dissolution Technologies 1919 (3), 2012 , 15-22.

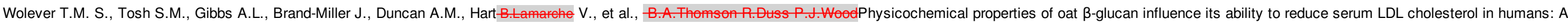
randomized clinical trial, American Journal of Clinical Nutrition 9292 (4), 2010, 723-732.

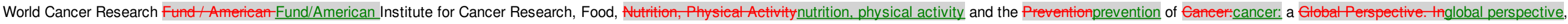
2007, AICR; Washington DC.

Wu A.H., Tseng C.C., Hankin J. and Bernstein L., Fiber intake and risk of adenocarcinomas of the esophagus and stomach, Cancer Causes and Control 1818 (7), 2007, 713-722.

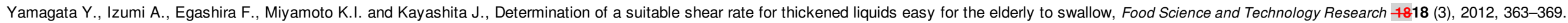
Yamaguchi M., Nakajima R. and Kasai K., Mechanoreceptors, Noeieepters,nociceptors, and Orthodontie Tooth Movementorthodontic tooth movement, Seminars in Orthodontics 1818 (4), 2012 , $249-256$.

Yeomans M.R., McCrickerd K., Brunstrom J.M. and Chambers L., Effects of repeated consumption on sensory-enhanced satiety, British Journal of Nutrition 111111 (6), $2014,1137-1144$.

Zhang J., Bowers J., Liu L., Wei S., Gowda G.A. N., HammoudD.Raftery Z., et al., Esophageal cancer metabolite biomarkers detected by LGASLC-MS and NMR methods, PLoS ENEOne 77, $2012,1$.

Zhang Z., Xu G., Ma M., Yang J. and Liu X., Dietary fiber intake reduces risk for gastric cancer: A meta-analysis, Gastroenterology 145 (1), 2013, 113-120, (e113).

Zolotarev V.A., Dietary free amino acids and the gastric phase of digestion, Current Pharmaceutical Design 2020 (16), 2014, 2731-2737.

\section{Graphical abstract}




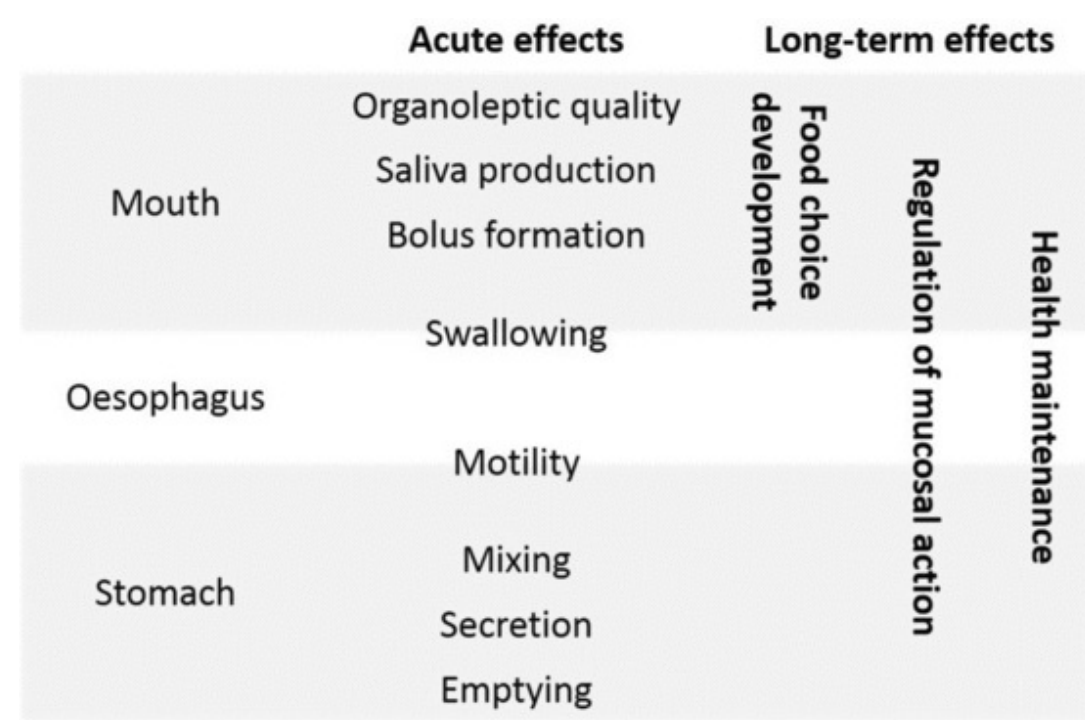

Highlights

- Dietary fibre's presence can affect foods' organoleptic quality, the process of swallowing and gastric secretion mixing and emptying.

- Dietary fibre can alter the rheological properties on gastrointestinal contents and access of chemosensors to other dietary factors.

- Consumption of higher amounts of fibre-rich plant foods is generally associated with reduced risk of upper gastrointestinal mucosal disease.

. "Added fibres" and inherent dietary fibre may not have comparable effects.

\section{Queries and Answers}

Query:

Please confirm that given name and surname have been identified correctly.

Answer: I can confirm this

Query:

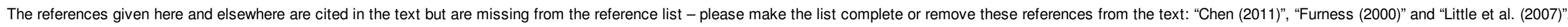
Answer: "Chen (2011)" should be "Chen (2009).

"Furness (2000)" relates to the following article:

Furness J.B. Types of neurons in the enteric nervous system, Journal of the Autonomic Nervous System 81 (1-3), 2000, 87-96. 


\section{elsevier_BCDF_68}

"Little et al., (2007)" relates to the following article:

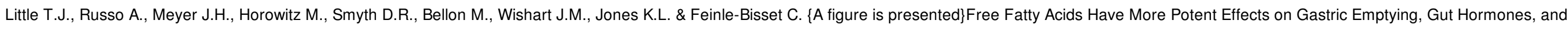

Appetite Than Triacylglycerides Gastroenterology 133 (4), 2007, 1124-1131.

Query:

The spelling of the author name(s) in the text has been changed to "Hellström, Grybäck, and Jacobsson (2006)" to match the reference list. Please check the spelling, and correct if necessary.

Answer: The spelling suggested by the Editors is correct and should be used both in-text and within the reference list. 